\title{
Invited review: Resource inputs and land, water and carbon footprints from the production of edible protein of animal origin
}

\author{
Gerhard Flachowsky ${ }^{1}$, Ulrich Meyer ${ }^{1}$, and Karl-Heinz Südekum ${ }^{2}$ \\ ${ }^{1}$ Institute of Animal Nutrition, Friedrich-Loeffler-Institut (FLI), Bundesallee 37, \\ 38116 Braunschweig, Germany \\ ${ }^{2}$ Institute of Animal Science, University of Bonn, Endenicher Allee 15, 53115 Bonn, Germany \\ Correspondence: Ulrich Meyer (ulrich.meyer@fli.de)
}

Received: 30 August 2017 - Revised: 17 November 2017 - Accepted: 24 November 2017 - Published: 18 January 2018

\begin{abstract}
The objective of this review is to analyze crucial factors in the output from the production of proteins in food of animal origin, such as milk, meat and eggs. We then consider inputs such as land, water, fuel, minerals and feed, as well as characterize emissions. Finally, we estimate footprints for land (land footprint, LF), water (water footprint, WF) and greenhouse gas emissions (i.e., carbon footprint, CF) during the production process. The wide range of different land and water inputs per unit feed between various studies largely influences the results. Further influencing factors are species and categories of animals that produce edible protein, their yields and the feeding of animals. Coproducts with no or low humanly edible fractions and grassland as feed contribute to a lower need for arable land and lower LF, WF and CF. The most efficient land use or the lowest LF per kilogram of edible protein was estimated for higher milk and egg yields; the highest LF values were calculated for beef, followed by pork. The lowest WF and CF were calculated for edible protein of chicken meat and eggs. Edible protein from ruminants is mostly characterized by a higher CF because of the high greenhouse gas potential of methane produced in the rumen. A key prerequisite for further progress in this field is the harmonization of data collection and calculation methods. Alternatives to partial or complete replacement of protein of terrestrial animals, such as marine animals, insects, cell cultures, single-cell proteins or "simulated animal products" from plants, as well as changing eating patterns and reducing food losses are mentioned as further potential ways for more efficient feed production. For all those dealing with plant or animal breeding and cultivation and all those who are working along the whole food production chain, it is a major challenge to enhance the production of more food for more people with, at the same time, less, limited resources and lower emissions.
\end{abstract}

\section{Introduction}

With the increase in population and higher need for feed and food, a growing demand arises for limited natural resources, and emissions with greenhouse gas (GHG) potential such as carbon dioxide $\left(\mathrm{CO}_{2}\right)$, methane $\left(\mathrm{CH}_{4}\right)$, nitrous oxide $\left(\mathrm{N}_{2} \mathrm{O}\right)$ and other substances (e.g., N, P, trace elements) become elevated. These challenges characterize edible protein production all over the world (Guillou and Matheron, 2014; NRC, 2015). "More for more with less" could be a headline to characterize the present situation and the challenges for agricul- tural sciences (Windisch et al., 2013). Malnutrition in all its forms - undernutrition, micronutrient deficiencies (e.g., iron, iodine, vitamin A) and overnutrition - the so-called "triple burden" of malnutrition, is still recognized as a serious and intractable problem of humanity (Tompson and Amoroso, 2014). The latest estimates indicate that about 800 million people are still chronically undernourished $(11.3 \%$ of the global population) (FAO et al., 2014). Some more people suffer from micronutrient deficiency. Food of animal nutrition, also called animal source food (Neumann et al., 2002), may contribute to overcoming micronutrient deficiencies. 
Table 1. Limited resources and emissions in the production of food of animal origin.

\begin{tabular}{ll}
\hline Limited resources & Emissions \\
\hline Land (especially arable land) & Carbon dioxide $\left(\mathrm{CO}_{2}\right)$ \\
Water & Nitrogen compounds \\
& $\left(\right.$ e.g., $\left.\mathrm{NH}_{3}, \mathrm{~N}_{2} \mathrm{O}\right)$ \\
Fuel/energy & Methane $\left(\mathrm{CH}_{4}\right)$ \\
Some minerals (e.g., P) & Some minerals (e.g., $\mathrm{P}, \mathrm{Cu}, \mathrm{Zn})$ \\
\hline
\end{tabular}

During the last few years many research groups have dealt with challenges and future developments for global food security (NRC, 2010; National Academies of Sciences, 2016; OECD/FAO, 2017), mainly under consideration of food of animal origin.

More recently, the NRC (2015) characterized the future by three general tendencies or developments:

- The global animal protein consumption will continue to increase based on population growth (from presently about 7.2 to about 9-10 billion people in 2050) and augmented per capita consumption of animal protein in many countries.

- Natural resources, such as land, water and energy, will be restricted and an increase in emissions and environmental changes, including climate change (see Table 1), is expected.

- Current and foreseeable rapid advances in basic biological sciences, as well as in social sciences and economics, will provide an opportunity to maximize the yield of investments in animal science research and development.

Protein of animal origin shall be the main topic of this review. The FAO (2009) estimates that there will be a $73 \%$ increase in meat and egg consumption and a $58 \%$ increase in dairy consumption compared to 2010 levels worldwide by the year 2050 .

The energy and protein conversion efficiency from feed into food of animal origin is low and may vary between $3 \%$ (energy - beef) and up to $40 \%$ (energy - dairy; protein chicken for fattening; Cassidy et al., 2013). In some countries (e.g., USA) between $67 \%$ (energy) and $80 \%$ (protein) of the crops are used as animal feed (Cassidy et al., 2013). These developments and complex connections lead to the question of whether there is any need for food of animal origin. As vegans demonstrate, there is no essential need for food of animal origin if the human diet is supplemented with all essential nutrients. However, the consumption of meat, fish, milk, eggs and insects may contribute significantly to meeting the human requirements for amino acids (D'Mello, 2012; Smith et al., 2013) and some important trace nutrients (such as $\mathrm{Ca}$, $\mathrm{P}, \mathrm{Zn}, \mathrm{Fe}, \mathrm{I}, \mathrm{Se}$ and vitamins $\mathrm{A}, \mathrm{D}, \mathrm{E}, \mathrm{B}_{12}$ ) especially for children juveniles, and for pregnant and lactating women. Human nutritionists recommend that about one-third of the daily protein requirements $\left(0.66-1 \mathrm{~g} \mathrm{~kg}^{-1}\right.$ body weight; e.g., Bauer et al. (2013) of adults should originate from protein of animal origin. Consequently, about $20 \mathrm{~g}$ of the recommended daily intake of about $60 \mathrm{~g}$ protein should be of animal origin, which is lower than the present average consumption (about $24 \mathrm{~g}$ ) throughout the world. It is a challenge for the future to overcome this imbalance (Smith et al., 2013). Meat, milk and eggs provide around $13 \%$ of the energy and $28 \%$ of protein consumed globally, with the higher share in the so-called developed countries (around 20 and $40 \%$, respectively; FAO, 2009).

Eating food of animal origin, especially meat, is not only a reflection of nutritional needs, but it is also determined by taste, odor and texture, as well as by geographical area, culture, ethics and wealth. Further reasons for the higher demand of food of animal origin in some countries are the increased income of the population (Kastner et al., 2012; Tilman et al., 2011) and the imitation of nutrition in a socalled "Western" style of life.

Alternatives to change the nutrition pattern and replace traditional foods of animal origin are discussed in Sect. 5.

Sustainable animal agriculture faces numerous challenges of meeting global food security in the context of environment, population and economy. The balance between the planet (global resources and emissions), people (social aspects of population all over the world) and profit (economic aspects, moneymaking) in the so-called 3P concept (Boonen et al., 2012; see Fig. 1 in this paper) is an important prerequisite for sustainable life and development on earth. Some authors are afraid that the balance between the three "P's" would become more and more disturbed and an ethical dimension should be introduced as the fourth dimension (Aiking, 2014; Makkar and Ankers, 2014). They believe that profit should certainly not be considered as the single objective of production.

Two options are available to overcome malnutrition:

(1) The production area and/or the number of animals can be increased.

(2) The productivity of land and animals can be improved (Edgerton, 2009).

In addition to previous contributions by our group to this topic (Niemann et al., 2011; Flachowsky and Kamphues, 2012; Flachowsky and Meyer, 2015a-c; Flachowsky and Meyer, 2017), the objective of this review is to analyze influencing factors on inputs and outputs of protein yield of various land animal protein sources such as milk, meat and eggs. Furthermore, we assess the inputs such as land, water, fuel and feed needed to produce food of animal origin. Additionally, we will characterize emissions and also calculate so-called footprints for land (LF), water (WF) and GHG emissions (carbon footprint, $\mathrm{CF}$ ) arising during production of 


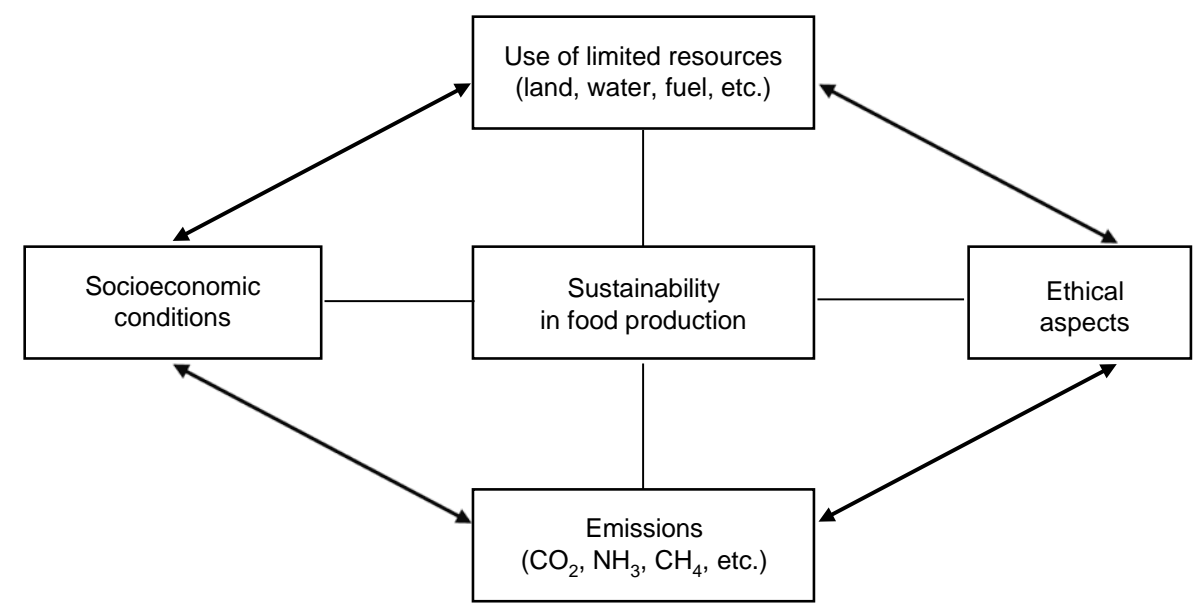

Figure 1. Sustainability as a balance between the use of limited natural resources, emissions, and socioeconomic and ethical conditions to produce food of animal origin (Flachowsky and Hachenberg, 2009).

food of animal origin. Finally, alternatives to traditional food proteins, such as aquaculture, insects, stem cells, simulated food of plant origin or changing the consumption pattern and reducing or avoiding of food losses are also discussed in Sect. 5.

\section{Edible protein in food of animal origin}

Providing humanly edible protein or, in other words, a group of essential amino acids (e.g., lysine, methionine, threonine, tryptophan) can be considered as the most important objective of animal husbandry. Table S1 in the Supplement shows the protein content of some food of land animal origin calculated by various authors and showing a considerable range of protein contents within and across studies. Except for milk, for their calculations, Mekonnen and Hoekstra (2010) used the lowest values for foods of animal origin when compared with estimates of other authors. For further calculations of the protein content of food of animal origin and various footprints (LF, WF and CF) for edible protein, data from our previous study (Flachowsky, 2002) will be used here.

The protein content of fish (filet) is given at 170$210 \mathrm{~g} \mathrm{~kg}^{-1}$ filet (e.g., Souci et al., 2006). Information about the protein content of insects as potential food is given in Table 17.

\section{Inputs}

\subsection{Land}

Land, especially arable land, is one of the most important limited factors. Only a small portion of the global surface (about 13.4 billion ha) is available as arable land (about 1.5 billion ha or about $12 \%$ of the world's land area (FAO, 2013). This area could be extended to a certain degree (by about 120 million ha; FAO, 2013) but some areas simply cannot be used because of limited water resources, forests, urban settlements, environmental protection, deserts, mountains and other influencing factors. As a result of the finite area of arable land and the increase in population, the area of arable land available per person decreased from about 0.45 ha (1960) to about 0.25 ha (2010) and will further decrease to below 0.20 ha per person after 2020. More details about land availability were described and discussed recently (Flachowsky et al., 2017).

Land use and land use changes are interconnected with GHG emission and may also influence CF (Hörtenhuber et al., 2014; FAO, 2017). Plant breeding can be considered as the starting point for the whole human food chain (Flachowsky et al., 2013b; National Academies of Sciences, 2016). Therefore, the production of high, stable and yields of highly digestible phytogenic biomass with low external inputs of nonrenewable resources, such as water, fuel, arable land or fertilizers, is a real future challenge for plant breeders. Further challenges are the decrease in emissions of gases with GHG potential during cultivation, as well as the creation of high resistance against biotic and abiotic stressors, including adaptation to potential climate change and tolerance against drought and other harsh environmental conditions. Another objective is a low concentration of undesirable substances in the plants (Flachowsky and Meyer, 2015b). Originally, animal nutrition was based on feed made of nonhumanly edible fractions, such as roughage and coproducts of foods and food processing. Later, cereal grains and other humanly edible fractions became feed for animals and the competition between man and animals started (Windisch et al., 2013). For our model calculations about the arable land need per unit of edible protein of animal origin, the plant yields from Table $\mathrm{S} 2$ are used. 
Apart from roughages and grains, coproducts from agriculture, such as cereal straw and sugar beet leaves, or from food production (e.g., cereal grain coproducts, oilseed coproducts) and the biofuel industry (e.g., distillers dried grains with solubles, rapeseed cake; Ertl et al., 2015; Knaus, 2012; Makkar, 2012; Wilkinson, 2011) are used in animal nutrition. This results in a more complicated calculation of arable land need for food of animal origin (Flachowsky et al., 2017). Some authors estimated humanly edible protein fractions of feeds and used these values (see Table S3) for ration planning. Expanded and improved utilization of food coproducts in animal feeding may decrease the pressure on the global grain demand.

From our view, it is incorrect, or at least a too simple view, to estimate the humanly edible fraction of forages and silages always as 0 (see Table S3; Wilkinson, 2011) because if produced on arable land, this could have been alternatively be used for cultivation of cereal grains or other edible cultures, as considered by Ertl et al. (2015) (Table S3).

\subsection{Water}

\subsubsection{Water in feed production}

Drinking water should be considered as one of the most important feeds or nutrients for animals. Mostly, animal nutritionists do not pay adequate attention to this feed. Therefore, some fundamentals of water as feed will be considered here (Legesse et al., 2017). Globally, water is one of the most limited natural resources (Pimentel et al., 2004). An adequate water supply for plants and animals is an indispensable prerequisite for healthy plants and animals and, likewise, high and stable yields (Jordaan and Bergman, 2017). There exist various calculations and estimations for water needs for adequate plant growth. Mekonnen and Hoekstra (2010) distinguish between green (naturally infiltrated into the soil), blue (water in rivers and aquifers) and grey (water required to assimilate the load of pollutants) water and calculated WF for various animal feeds (Table 2).

For more general calculations, Mekonnen and Hoekstra (2010) also give summarized values for concentrates and roughages (Table 3 ). Such values are used for further calculation in animal feeding and calculation of WF, but the calculation basis of these values it is not really clear. According to Hoekstra (2016), the WF was developed and applied within the water resources research. It is, however, questionable, if green (rain) and/or grey water should be considered for calculation of WF. Rain falls down, irrespective of whether is on grassland, arable land, forest, wasteland or settlement area. The grass can be used by (wild or domestic) animals, preserved as hay or silage, burned as heating material or it can rot on the grassland without human influence. Presently, grass use is more or less determined by chance, but it is considered in calculations of WF for forage or roughage as feed for animals. It should be possible to distinguish between wa-
Table 2. Water footprint (WF; sum of green, blue and grey water) of some selected plant products (Mekonnen and Hoekstra, 2010).

\begin{tabular}{lcc}
\hline Plant product & $\begin{array}{c}\text { WF } \\
\left(\mathrm{m}^{3} \mathrm{~kg}^{-1}\right)\end{array}$ & $\begin{array}{c}\text { WF } \\
\left(\mathrm{m}^{3} \mathrm{MJ}^{-1}\right)\end{array}$ \\
\hline Sugar crops & 0.20 & 2.9 \\
Vegetables (for food) & 0.32 & 5.6 \\
Potatoes (starchy roots) & 0.39 & 2.0 \\
Cereal grains & 1.64 & 2.1 \\
Wheat & 1.83 & \\
Barley & 1.35 & \\
Maize & 1.22 & \\
Oil crops & 2.36 & 3.4 \\
Soybeans & 2.14 & \\
Pulses & 4.06 & 5.0 \\
\hline
\end{tabular}

Table 3. Average water footprint (WF; green, blue, grey and total; $\mathrm{m}^{3} \mathrm{t}^{-1}$ ) for concentrates and roughages (Mekonnen and Hoekstra, 2010).

\begin{tabular}{lrrrr}
\hline Type of feed & Green WF & Blue WF & Grey WF & Total WF \\
\hline Concentrates & 849 & 78 & 122 & 1048 \\
Roughages & 199 & 1.8 & 2 & 203 \\
\hline
\end{tabular}

ter useable for human purposes and water that cannot be used by humans (e.g., rainwater on grassland). Animals, which consume such feeding stuffs from grassland, may contribute to stabilizing and improving human nutrition. There is no direct competition with human use purposes. Conversely, if rain falls on arable land, which could be used to cultivate food and feed plants for the human food chain, such water may well be considered in the WF. As an alternative, water could be differentiated into potentially humanly usable water, on the one side, as done in animal nutrition for humanly edible feeds or humanly edible protein and energy (e.g., Ertl et al., 2015; Wilkinson, 2011), and non-humanly usable water (not considered in the WF), on the other side.

\subsubsection{Water need for animal husbandry and drinking}

Compared with the water need for feed production (compare Tables 2 and 3) only small amounts are required for animal management and drinking. The calculation of the WF for animal products includes the water required for feed production (about $98 \%$ of total water; Gerbens-Leenes et al., 2013; Mekonnen and Hoekstra, 2010), drinking water for animals (about 1\%; Meyer et al., 2004, 2006) and management water (<1\%; Krauss et al., 2016; Schlink et al., 2010).

Water need for animal farm management and hygiene, as well as for drinking

Despite the low water intake by animals in comparison with the water need for plant growth (see Sect. 3.2.1), particular 
consideration is to be given to water intake by animals because of the high importance for animal health and yields. Drinking water should be characterized by an adequate quality (Kamphues et al., 2007; see Table 4 in this paper). The specification of quality of drinking water for animals in the EU generally follows WHO (2006) and is characterized by the following statement:

Water for drinking and aquaculture should be suitable for this specific animal species/category. In the case of specific doubts concerning a contamination of animals and/or food of animal origin by water for drinking, measurements to assess and to minimize the risks are required.

Conversely, an insufficient supply of drinking water of an adequate quality will result in adverse effects on animal health, performance and welfare as well as on the quality of food of animal origin (e.g., NRC, 1998; GfE, 2001; Kamphues et al., 2007). Adequate quality of drinking water is necessary for animal health and productivity and may also influence animal yields and finally WF. Various national recommendations have been published about tolerable concentrations of a number of ingredients in drinking water (see Table 4 for German recommendations). In some cases (e.g., $\mathrm{F}, \mathrm{Cu}, \mathrm{Zn}$ ), the German parameters for drinking water suitability are stricter for animals than in the human regulations (see Table 4).

\section{Water intake}

In recent years, several authors have studied the water intake of animals depending on various factors like animal species and categories, animal performances, environmental conditions, diet composition, and water content of feeds. Tedeschi and Fox (2016) describe, in detail, influencing factors on water intake, such as feed composition, milk yield, environmental temperature, mud, breed, body fat content and stage of pregnancy. Table 5 shows some proportions between dry matter (DM) and water intake for important food-producing animals and horses as well as factors possibly influencing water intake.

Equations to calculate the water intake under consideration of certain variables are shown in Table 6 for ruminants. Similar equations are given for pigs (Table 7) and horses (Table 8). Animals lose water primarily through urine, faeces, pulmonary and cutaneous evaporation, and in the case of lactating or laying animals also via milk and eggs.

Cattle cover the largest part of their water demand through drinking. A smaller part of the need is usually satisfied by the intake of water included in feedstuffs. This portion depends on diet composition. It is higher in grazing animals and in animals fed with silage in comparison to dry feeds. The third and less important source is water originating from the metabolic oxidation of nutrients, mainly carbohydrates (Kolb, 1989). From the oxidation of $1 \mathrm{~kg}$ of fat, carbohy- drates or protein, $1.07,0.60$ or $0.42 \mathrm{~L}$ of water, respectively, is produced (Schiavon and Emmans, 2000).

Numerous factors have effects on the voluntary water intake of ruminants. These factors can be divided into two subcategories: (1) animal factors such as animal species and categories, body size, activity level, animal feeding (including salt intake), and yield and (2) environmental factors such as ambient temperature, relative humidity and wind velocity (e.g., GfE, 2001; Kamphues et al., 2007; Meyer et al., 2004, 2006). Further research is needed to unveil the mechanisms used by animals that are resilient to water shortage and to determine how to increase water use efficiency in livestock.

Compared with ruminants, fewer studies about water intake are available for pigs (Table 7). Some detailed information about water intake of pigs of various age groups (2$5 \mathrm{Lkg}^{-1}$ feed; see Table 7) are given by GfE (2008). The higher values per kilogram of feed probably result from water losses during drinking (GfE, 2008).

Nagai et al. (1994) measured the water intake of suckling pigs aged from 1 to 28 days. They began to drink water 3 to $5 \mathrm{~h}$ after birth. Water intake increased from $36 \mathrm{mLday}^{-1}$ at the age of 1 day to $403 \mathrm{mLday}^{-1}$ at the age of 28 days. Water consumption per kilogram of body weight remained constant between 51 and $62 \mathrm{~mL}$.

For horses under normal keeping and feeding conditions, GfE (2014) sets a water intake between 3 and $3.5 \mathrm{~L} \mathrm{~kg}^{-1} \mathrm{DM}$ intake. In case of stronger work and higher temperatures, up to $7 \mathrm{~L} \mathrm{~kg}^{-1} \mathrm{DM}$ intake can be measured. These values agree with data by Martin-Rosset et al. (2015) presented in Table 8 .

\subsection{Further inputs}

\subsubsection{Fuels}

Fuel is used in various forms (e.g., diesel, coal, gas, electricity) in many fields of agriculture (Frorip et al., 2012). Mikkola and Ahokas (2009) calculated a fuel consumption of between 55 and $60 \mathrm{~L} \mathrm{ha}^{-1}$ from measurements in central Europe, but Jokiniemi et al. (2012) measured 65-74 $\mathrm{L} \mathrm{ha}^{-1}$ grassland in Finland when baling and loader wagon operations for hay were included. Because of many influencing factors, these details will not be considered in the following calculations (e.g., Ahlgrimm et al., 2000).

\subsubsection{Agrochemicals}

Jokiniemi et al. (2012) conclude that the highest energy consumptions in plant production originate from agrochemicals, such as fertilizers, lime and pesticides. Mikkola and Ahokas (2009) calculated an indirect energy input in the form of agrochemicals of between 54 and $73 \%$ of the total energy input. Rathke et al. (2002) found a correlation between fertilization and energy balance. Other authors (e.g., Rathke and Diepenbrock, 2006; Thorup-Kristensen et al., 2003) describe large ranges in energy input depending on plant culture and 
Table 4. Recommendations to assess chemical and physicochemical quality of drinking water according to feed and food safety (Kamphues et al., 2007).

\begin{tabular}{|c|c|c|c|c|}
\hline & Unit & $\begin{array}{l}\text { Range or boundary values } \\
\text { for suitability as drinking } \\
\text { water for animals }\end{array}$ & $\begin{array}{l}\text { Comments and remarks (possible } \\
\text { disturbances) }\end{array}$ & $\begin{array}{l}\text { Limits for drinking wa- } \\
\text { ter according to human } \\
\text { regulations (Germany) }\end{array}$ \\
\hline \multicolumn{5}{|c|}{ Physicochemical characteristics } \\
\hline $\mathrm{pH}^{\mathrm{e}}$ & & $>5<9$ & Corrosion of water pipes & $6.5-9.5$ \\
\hline Electrical conductivity & $\mu \mathrm{Scm}^{-1}$ & $<3000$ & $\begin{array}{l}\text { Higher values may be associated } \\
\text { with diarrhea, reduced taste }\end{array}$ & 2500 \\
\hline Soluble salts; total & $\mathrm{g} \mathrm{L}^{-1}$ & $<2.5$ & & \\
\hline Oxidable $^{f}$ & $\mathrm{mgL}^{-1}$ & $<15$ & $\begin{array}{l}\text { Measurement for oxidation poten- } \\
\text { tial in water }\end{array}$ & 5 \\
\hline
\end{tabular}

\begin{tabular}{|c|c|c|c|c|}
\hline \multicolumn{5}{|c|}{ Chemical substances } \\
\hline Ammonia $\left(\mathrm{NH}_{4}^{+}\right)$ & $\mathrm{mgL}^{-1}$ & $<3$ & Indication of impurities & 0.5 \\
\hline Arsenic (As) & $\mathrm{mgL}^{-1}$ & $<0.05$ & Health disturbances, reduced yields & 0.01 \\
\hline Lead $(\mathrm{Pb})$ & $\mathrm{mgL}^{-1}$ & $<0.1$ & Avoidance of residues & 0.01 \\
\hline Cadmium (Cd) & $\mathrm{mgL}^{-1}$ & $<0.02$ & Avoidance of residues & 0.005 \\
\hline Calcium $(\mathrm{Ca})^{\mathrm{g}}$ & $\mathrm{mgL}^{-1}$ & 500 & $\begin{array}{l}\text { Lime scale in pipelines, technical } \\
\text { malfunctions }\end{array}$ & Presently no limit \\
\hline Chlorine $\left(\mathrm{CI}^{-}\right)$ & $\mathrm{mgL}^{-1}$ & $<250^{\mathrm{a}}$ & $\begin{array}{l}\text { Indication of contamination (e.g., } \\
\text { faeces), wet excreta }{ }^{a}\end{array}$ & 250 \\
\hline Iron $(\mathrm{Fe})^{\mathrm{g}}$ & $\mathrm{mgL}^{-1}$ & $\begin{array}{l}<500^{\mathrm{b}} \\
<3\end{array}$ & $\begin{array}{l}\text { Palatability influenced, technical } \\
\text { malfunctions, biofilms, antagonist } \\
\text { to other trace elements }\end{array}$ & 0.2 \\
\hline Fluorine (F) & $\mathrm{mgL}^{-1}$ & $<1.5$ & Disturbances of teeth and bones & 1.5 \\
\hline Potassium (K) & $\mathrm{mgL}^{-1}$ & $\begin{array}{l}<250^{\mathrm{a}} \\
<500^{\mathrm{b}}\end{array}$ & see chlorine $^{\mathrm{a}}$ & Presently no limit \\
\hline Copper $(\mathrm{Cu})^{\mathrm{h}}$ & $\mathrm{mg} \mathrm{L}^{-1}$ & $<2$ & $\begin{array}{l}\text { Consider total intake of sheep and } \\
\text { calves }\end{array}$ & 2 \\
\hline Manganese (Mn) & $\mathrm{mgL}^{-1}$ & $<4$ & $\begin{array}{l}\text { Precipitation in water distribution } \\
\text { system, biofilms possible }\end{array}$ & 0.05 \\
\hline Sodium (Na) & $\mathrm{mgL}^{-1}$ & $\begin{array}{l}<250^{\mathrm{a}} \\
<500^{\mathrm{b}}\end{array}$ & see chlorine $\mathrm{a}^{\mathrm{a}}$ & 200 \\
\hline Nitrate $\left(\mathrm{NO}_{3}^{-}\right)$ & $\mathrm{mgL}^{-1}$ & $\begin{array}{l}<300^{\mathrm{c}} \\
<200^{\mathrm{d}}\end{array}$ & $\begin{array}{l}\text { Methemoglobinemia possible, con- } \\
\text { sider total } \mathrm{NO}_{2} \text { and } \mathrm{NO}_{3} \text { intake }\end{array}$ & 50 \\
\hline Nitrite $\left(\mathrm{NO}_{2}^{-}\right)$ & $\mathrm{mgL}^{-1}$ & $<30$ & & 0.5 \\
\hline Mercury (Hg) & $\mathrm{mgL}^{-1}$ & $<0.003$ & General disturbances, intoxications & 0.001 \\
\hline Sulfate $\left(\mathrm{SO}_{4}^{2-}\right)$ & $\mathrm{mgL}^{-1}$ & $<500$ & Diarrhea & 240 \\
\hline Zinc $(\mathrm{Zn})^{\mathrm{i}}$ & $\mathrm{mgL}^{-1}$ & $<5$ & Mucous membrane alterations & Presently no limit \\
\hline
\end{tabular}

agricultural management. Kool et al. (2012) analyzed the energy input for production of fertilizers such as $\mathrm{N}, \mathrm{P}$, and $\mathrm{K}$ fertilizer and calculated footprints per kilogram of fertilizer (Table 9). The values are characterized by large ranges, too.

Another point is the limited availability of some plant nutrients. This limitation mainly relates to phosphorous (Hall and Hall, 1984; Scholz and Wellmer, 2013). Two recent papers propose a hierarchy of limited natural resources with phosphorus at the top and suggest replacing fossil fuel en- ergy (Wellmer and Scholz, 2017, 2016). Therefore, animal excreta should be efficiently used in order to save inorganic resources (Talgre et al., 2009; Thyberg and Tonjes, 2017). Nitrogen is available in almost unlimited amounts in the air, but its potential to be obtained as an aerial plant nutrient is presently only used by legumes. 
Table 5. Dry matter (DM) and water intake (in relation to DM intake) of various animal species and categories (Kamphues et al., 2014).

\begin{tabular}{lrrl}
\hline $\begin{array}{l}\text { Animal species/ } \\
\text { category }\end{array}$ & $\begin{array}{r}\text { DM intake } \\
\text { (\% of body weight })^{*}\end{array}$ & $\begin{array}{r}\text { Water-to-DM intake ratio } \\
\left(\mathrm{Lkg}^{-1}\right)\end{array}$ & $\begin{array}{l}\text { Possibly influencing } \\
\text { factors }\end{array}$ \\
\hline Cattle & $2-4$ & $3-5$ & Milk yield, temperature \\
Dairy cow & 2 & & \\
Beef cattle, heifer & $2-3$ & $3-4$ & Milk yield, temperature \\
\hline Sheep & 4 & $2-2.5$ & \\
\hline Ewe & $2.5-6$ & $3.5-4$ & Milk yield, temperature \\
Fattening lamb & $2-3$. & $2-4$ & Work, sweat, temperature \\
\hline Goat (milk) & 5 & $>5$ & \\
\hline Horses & & $3-4$ & Milk yield, temperature \\
Work & $2-3$ & $3(2-4)$ & \\
\hline Pigs & $3-5$ & $2-5$ & Temperature \\
\hline Sow & $5-8$ & $2-5$ & Temperature \\
\hline Fattening pigs & $7-13.5$ & $2-5$ & Temperature \\
\hline Laying hen & $3-10$ & $3.5-5$ & Temperature \\
\hline Chicken for fattening & $7-12.5$ & & \\
\hline Turkey for fattening & & & \\
\hline Duck (Peking) & & & \\
\hline
\end{tabular}

* High values for high yields and young animals.

Table 6. Some equations to predict the water intake of ruminants depending on various influencing factors by several authors.

\begin{tabular}{|c|c|c|}
\hline Species & Equations, $y$ : water intake $\left(\mathrm{Lday}^{-1}\right)$ & Authors \\
\hline $\begin{array}{l}\text { Dairy cows } \\
\text { (Lactation) }\end{array}$ & $\begin{array}{l}y=15.3+2.52 \times \text { milk yield }\left(\mathrm{kg} \mathrm{day}^{-1}\right)+0.45 \times \mathrm{DM}^{\mathrm{a}} \text { content of ration }(\%) \\
y=15.99+1.58 \times \mathrm{DM} \text { intake }\left(\mathrm{kg} \mathrm{day}^{-1}\right)+0.9 \times \text { milk yield }\left(\mathrm{kg} \mathrm{day}^{-1}\right)+0.05 \times \\
\text { Na intake }\left(\mathrm{g} \mathrm{day}^{-1}\right)+1.2 \times \text { minimal night temperature }\left({ }^{\circ} \mathrm{C}\right) \\
y=14.3+1.28 \times \text { milk yield }\left(\mathrm{kg} \mathrm{day}^{-1}\right)+0.32 \times \mathrm{DM} \text { content of ration }(\%) \\
y=-26.12+1.516 \times \text { average of environment temperature }\left({ }^{\circ} \mathrm{C}\right)+1.299 \times \\
\text { milk yield }\left(\mathrm{kg} \mathrm{day}^{-1}\right)+0.058 \times \text { body weight }(\mathrm{kg})+0.406 \times \mathrm{Na}^{\mathrm{b}} \text { intake }\left(\mathrm{g} \mathrm{day}^{-1}\right)\end{array}$ & $\begin{array}{l}\text { Castle and Thomas (1975) } \\
\text { Murphy et al. (1983); } \\
\text { NRC (2001) } \\
\text { Dahlborn et al. (1998) } \\
\text { Meyer et al. (2004) }\end{array}$ \\
\hline $\begin{array}{l}\text { Dairy cows } \\
\text { (dry) }\end{array}$ & $\begin{array}{l}y=-10.34+0.2296 \times \mathrm{DM} \text { content of ration }(\%)+2.212 \times \mathrm{DM} \text { intake }\left(\mathrm{kg} \mathrm{day}^{-1}\right)+ \\
0.03944 \times \mathrm{CP}^{\mathrm{c}} \text { content of ration }(\% \text { of } \mathrm{DM}) \\
y=1.16 \times \mathrm{DM} \text { intake }+0.23 \times \mathrm{DM} \text { content }+0.44 \times \text { current temperature }+0.061 \times \\
(\text { current temperature }-16.4)^{2} \\
y=0.01 \times \text { body weight }+0.32 \times \mathrm{DM} \text { content }+0.52 \times \text { current temperature }+0.053 \times \\
(\text { current temperature }-16.4)^{2}\end{array}$ & $\begin{array}{l}\text { Holter and Urban (1992) } \\
\text { Tedeschi and Fox (2016) } \\
\text { Tedeschi and Fox (2016) }\end{array}$ \\
\hline Beef cattle & $\begin{array}{l}y=-3.85+0.507 \times \text { average of environmental temperature }\left({ }^{\circ} \mathrm{C}\right)+1.494 \times \\
\text { DM intake }\left(\mathrm{kg} \mathrm{day}^{-1}\right)-0.141 \times \text { roughage of ration }(\% \text { of } \mathrm{DM})+0.248 \times \\
\text { DM content of roughage }(\%)+0.014 \times \text { body weight }(\mathrm{kg})\end{array}$ & Meyer et al. (2006) \\
\hline Heifers & $\begin{array}{l}y=-5.206+0.038 \times \text { body weight }(\mathrm{kg})+0.610 \times \text { average of environmental } \\
\text { temperature }\left({ }^{\circ} \mathrm{C}\right)+0.098 \times \text { roughage of ration }(\% \text { of DM })-0.086 \times \\
\text { relative air moisture }(\%)+0.530 \times \mathrm{DM} \text { intake }\left(\mathrm{kg} \mathrm{day}^{-1}\right)\end{array}$ & Grabow et al. (2009) \\
\hline Sheep & $y=3.86 \times \mathrm{DM}$ intake -0.99 & NRC (2007); Forbes (1986) \\
\hline
\end{tabular}

${ }^{a}$ Dry matter. ${ }^{b}$ Sodium. ${ }^{c}$ Crude protein. 
Table 7. Equations to predict the water intake of pigs depending on various influencing factors by some authors.

\begin{tabular}{lll}
\hline Category & Calculation equations $\left(y\right.$ : water intake; $\left.\mathrm{Lday}^{-1}\right)$ & Authors \\
\hline $\begin{array}{l}\text { Lactating sows (third } \\
\text { week of lactation) }\end{array}$ & $y$ (in relation to feed intake; $\mathrm{FI}^{\mathrm{a}}=2.52 \times \mathrm{FI}\left(\mathrm{kg} \mathrm{d}^{-1}\right)+4.22$ & Gill (1989) \\
\hline Fattening pigs & $y$ (in relation to body mass; $\left.\mathrm{BW}^{\mathrm{b}}\right)=0.01 \times \mathrm{BW}(\mathrm{kg})+16.1$ & \\
& $y$ (in relation to $\mathrm{FI})=2.13 \times \mathrm{FI}\left(\mathrm{kg} \mathrm{day}^{-1}\right)+1.57$ & Schiavon and Emmans (2000) \\
\hline Piglets & $y=0.149+3.053 \times \mathrm{DM}^{\mathrm{c}}$ intake $\left(\mathrm{kg} \mathrm{day}^{-1}\right)$ & \\
& $y=0.788+2.23 \times \mathrm{DM}$ intake $\left(\mathrm{kg} \mathrm{day}^{-1}\right)+0.367 \times \mathrm{kg} \mathrm{BW}^{0,6}$ & Brooks et al. (1984) \\
Weeks 1-9 & $y=\left(0.48+1.13 \mathrm{DM} \text { intake; } \mathrm{kg} \mathrm{day}^{-1}\right)^{2}$ & Gill (1989) \\
Weaned piglets & $y=\left(0.61+1.06 \mathrm{DM} \text { intake; } \mathrm{kg} \mathrm{day}^{-1}\right)^{2}$ & Gill (1989) \\
\hline
\end{tabular}

${ }^{a}$ Feed intake. ${ }^{b}$ Body weight. ${ }^{c}$ Dry matter.

Table 8. Total water intake of horses related to dry matter and body weight at an ambient temperature of $15^{\circ} \mathrm{C}$ (Martin-Rosset et al., 2015 ).

\begin{tabular}{|c|c|c|c|}
\hline Type of ration & Physiological state & $\begin{array}{r}\text { Water intake } \\
\left(\mathrm{L} \mathrm{kg} \mathrm{DM}^{*} \text { intake }^{-1}\right)\end{array}$ & $\begin{array}{r}\text { Water intake } \\
(\mathrm{L} 100 \mathrm{~kg} \text { body weight }\end{array}$ \\
\hline $\begin{array}{l}\text { Mixed ration } \\
\text { (Roughage plus } \\
>15 \% \text { concentrate) }\end{array}$ & $\begin{array}{l}\text { Growing and adult } \\
\text { horses (maintenance) }\end{array}$ & $3.0-3.5$ & $5.0-6.0$ \\
\hline Primarily roughage & Mare (early pregnancy) & $3.5-4.0$ & $6.0-7.0$ \\
\hline $\begin{array}{l}\text { Mixed ration } \\
\text { (Roughage plus } \\
>15 \% \text { concentrate) }\end{array}$ & Mare (early lactation) & 4.5 & $10.0-11.0$ \\
\hline Primarily roughage & Mare (late lactation) & 4.0 & $9.0-10.0$ \\
\hline $\begin{array}{l}\text { Mixed ration } \\
\text { (Roughage plus } \\
>15 \% \text { concentrate) }\end{array}$ & $\begin{array}{l}\text { Light work } \\
\text { Middle work } \\
\text { Heavy work }\end{array}$ & $\begin{array}{r}3.0-4.0 \\
4.0 \\
4.5-5.0\end{array}$ & $\begin{array}{r}6.0-7.0 \\
8.0-9.0 \\
9.5-10.5\end{array}$ \\
\hline
\end{tabular}

* Dry matter.

Table 9. Examples for emissions during production of fertilizers (kg CO 2 eq. $\mathrm{kg}^{-1}$ product; Kool et al., 2012).

\begin{tabular}{lr}
\hline Fertilizer $(\mathrm{kg})$ & $\mathrm{kg} \mathrm{CO} 2$ eq. \\
\hline $\mathrm{N}$ & $5.66(3.42-8.43)$ \\
$\mathrm{P}_{2} \mathrm{O}_{5}$ & $1.36(0.14-2.15)$ \\
$\mathrm{K}_{2} \mathrm{O}$ & $1.23(0.36-1.91)$ \\
Lime & $0.074(0.054-0.089)$ \\
\hline
\end{tabular}

\subsection{Feeds and feeding}

Sufficient amounts of high-quality feeds are the most important prerequisites for a sustainable production of protein of animal origin, as previously summarized (Flachowsky and Meyer, 2015a, c). Challenges for plant breeders to develop adequate plants were recently reviewed and summarized and will therefore not be discussed in detail here (see Flachowsky and Meyer, 2015b; National Academies of Sciences, 2016).
Information about the level of feed intake, the roughage-toconcentrate ratio and the influence of coproducts on animal yields are shown in the following tables in more detail.

Tilman et al. (2011) estimate nearly a doubling of global needs for cereal grain between 2005 and 2050. This seems to be impossible to meet and elimination or reduction of cereals from animal rations is required. Coproducts from the food and biofuel industry may replace 50 to $100 \%$ of cereal grains or protein sources in animal nutrition, particularly for ruminants (e.g., Knaus, 2012). Ruminants are very efficient in converting fibrous forages including coproducts from agriculture (e.g., cereal straw; Flachowsky, 1987), which are characterized by a high fiber content. Chemical treatments of such low-quality roughages (e.g., Jentsch et al., 1978a, b; Ochrimenko et al., 1986) may also improve the feed base.

Tables S4 and S5 show coproducts exemplarily used as a replacement for cereal grains and other human foods and the resulting influence on the so-called protein score. A protein score greater than 1 demonstrates a more efficient conver- 
sion from feed into humanly edible protein than values lower than 1 .

Very high milk yields ( $40 \mathrm{~kg}$ per day; Table S4) require more cereals or more humanly edible protein in the diet and the protein score is lower than 1 . That means that the consumed humanly edible protein fraction is larger than the protein output via milk. Of concentrate, $50 \%$ is replaced by coproducts in rations of the most important food-producing animals (Table S5) under consideration of a middle level of yield. In all cases, the protein score increased with replacement of concentrate by coproducts.

The content of insects as potential food is given in Table 17 .

\section{Outputs}

\subsection{Edible protein yield}

Table S6 shows the influence of animal species/categories and animal yield level on DM intake, expected roughage-toconcentrate ratio and the edible protein yield per day. These values can be considered as the starting point for all adequate calculations.

The protein output is mainly influenced by animal species and yields of animals. Optimal feeding of animals on the basis of scientific knowledge about energy and nutrient requirements is an important prerequisite for adequate yields.

\subsection{Land and land footprints}

Land use for edible protein of animal origin is mainly influenced by animal species and animal yield, as recently demonstrated (de Vries and de Boer, 2010; Flachowsky et al., 2017; Nijdam et al., 2012).

\subsubsection{Influence of crop yield, land use and coproducts}

Important influencing factors are the land used (grassland or arable land), the kind of cultivated crops and their yields (Table S7), and the replacement of cultivated crops with coproducts (Table S8). The higher the animal performances and the greater the plant yields, the lower the land areas required to produce $1 \mathrm{~kg}$ of edible protein of animal origin.

Analogue tendencies are observed in the calculations after replacement of cereals with coproducts.

\subsubsection{Miscellaneous factors}

Apart from plant and animal yields, the LF of grassland and coproduct feeding to animals is also substantially influenced by additional factors such as

- changes in nutritional quality of crops (e.g., low content of antinutritive substances; increased content of amino acids achieved by plant breeding; Flachowsky et al., 2013a; National Academies of Sciences, 2016);
- feeding according to energy and nutrient requirements depending on animal species, categories and performance;

- high quality of roughages (e.g., pasture, hay, silages; Tedeschi and Fox, 2016);

- optimal supplementation of rations with mixed feeds, feed additives (Pape, 2006) and bio-fortified plants (Parisi et al., 2016);

- adequate protein supply and amino acid supplementation, which is important not only for animal performance but also to minimize $\mathrm{N}$ excretion and GHG emissions;

- adequate farm and veterinarian service to assure high animal welfare and to avoid diseases and reduce animal mortality.

\subsubsection{Data variability}

Large ranges in land use per kilogram of edible protein have also been reported by others (Tables S9 and S10). Ridoutt et al. (2014) analyzed six diverse beef cattle systems in southern Australia and found $86-172 \mathrm{~m}^{2}$ of land per kilogram of animal live weight. For beef cattle, similar values and large ranges are shown in Tables S9 and S10. The smallest area is needed per kilogram of protein of chicken meat, eggs and milk, followed by pork. Extensive pastoral systems require the largest area, but the plant yields are very low. Still, this land offers no alternative possibilities for agricultural use.

\subsection{Water and water footprints}

The sum of WF results from green, grey and blue water (Mekonnen and Hoekstra, 2010). The term WF had been developed and applied within water resource research and should also be used in the future in other areas of research and application (Hoekstra, 2016). Based on water need for feed (e.g., $1048 \mathrm{~L} \mathrm{~kg}^{-1}$ concentrate; $203 \mathrm{~L} \mathrm{~kg}^{-1}$ roughage; see Table 3), some authors calculated WF for food of animal origin. The first studies were carried out by Hoekstra (2010). Then later papers (e.g., Mekonnen and Hoekstra, 2012) were based on or cited data from Hoekstra (2010). The low water need for drinking and management is mostly neglected there. In our own calculation, we assumed $2 \%$ for these purposes. Table 10 shows the influence of milk yield and coproduct portion on the WF per kilogram of milk and per kilogram of edible protein.

In many cases, though, it is not clear if the calculation data are expressed on feed base (original matter) or as fed to animals (not on DM base). This, however, leads to highly different interpretations.

Table 11 demonstrates the influence of various rations on daily weight gain of bulls and the WF per kilogram of body 
Table 10. Model calculation of water footprint (WF) for milk depending on milk yield and coproducts in feeding.

\begin{tabular}{|c|c|c|c|c|c|c|c|c|}
\hline $\begin{array}{l}\text { Milk yield } \\
\left(\operatorname{kg~day}^{-1}\right)\end{array}$ & $\begin{array}{r}\mathrm{DM}^{\mathrm{a}}- \\
\text { intake }^{\mathrm{b}} \\
\left(\mathrm{kg} \mathrm{day}^{-1}\right)\end{array}$ & $\begin{array}{r}\text { Roughage } \\
\text { part } \\
\text { (\%; DM base) }\end{array}$ & $\begin{array}{r}\text { Coproducts } \\
\text { in concen- } \\
\text { trate }(\%)\end{array}$ & $\begin{array}{r}\text { Concentrate } \\
\text { intake } \\
\left(\mathrm{kg} \mathrm{DM} \mathrm{day}^{-1}\right)\end{array}$ & $\begin{array}{r}\text { Coproduct } \\
\text { intake } \\
\left(\mathrm{kg} \mathrm{day}^{-1}\right)\end{array}$ & $\begin{array}{r}\text { Water intake } \\
\text { via feed } \\
\left(\mathrm{L} \mathrm{day}^{-1}\right)\end{array}$ & $\begin{array}{r}\mathrm{WF} \\
(\mathrm{Lkg} \\
\left.\mathrm{milk}^{-1}\right)\end{array}$ & $\begin{array}{r}\text { WF } \\
\left(\mathrm{m}^{3} \mathrm{~kg} \text { edible }\right. \\
\left.\text { protein }^{-1}\right)\end{array}$ \\
\hline 5 & 10 & 95 & $100^{c}$ & 0.5 & 0.5 & 1930 & 386 & 11.4 \\
\hline 10 & 12 & 90 & $100^{\mathrm{c}}$ & 1.2 & 1.2 & 2190 & 219 & 6.4 \\
\hline 20 & 16 & 75 & $50^{\mathrm{d}}$ & 4.0 & 2.0 & 4530 & 226 & 6.6 \\
\hline 40 & 25 & 50 & $25^{\mathrm{e}}$ & 12.5 & 3.12 & 12390 & 310 & 9.1 \\
\hline
\end{tabular}

${ }^{a}$ Dry matter. ${ }^{\mathrm{b}}$ WF of feed from Mekonnen and Hoekstra (2010): $1048 \mathrm{~L} \mathrm{~kg} \mathrm{concentrate}{ }^{-1} ; 203 \mathrm{~L} \mathrm{~kg} \mathrm{roughage}{ }^{-1}$; see Table $3 .^{\mathrm{c}}$ Includes $25 \%$ wheat bran; $25 \%$ dried sugar beet pulp. ${ }^{\mathrm{d}}$ Includes $30 \%$ cereal grains; $10 \%$ soybean meal; $10 \%$ rapeseed meal. ${ }^{\text {e }}$ Includes $12.5 \%$ wheat bran; $12.5 \%$ dried sugar beet pulp; $50 \%$ cereal grains; $15 \%$ soybean meal; $10 \%$ rapeseed meal.

weight gain, per kilogram of beef and per kilogram of edible protein.

Calculations in Tables 10 and 11 show considerably lower WF than data by Hoekstra (2010) and Mekonnen and Hoekstra (2012), as presented in Table 12. No reasons for the differences are obvious. Zonderland-Thomassen et al. (2014) calculated WF of beef cattle and sheep production systems in New Zealand and came to the conclusion that the need for a harmonized methodology and specific local contextual information is an important factor when interpreting the results.

Table 13 summarizes the water need for feed production, management water and drinking water. Based on these data, WF per kilogram of product and per kilogram of edible protein were calculated. The differences between numbers in Tables 10 and 11 in comparison to Table 13 are based on a certain portion of coproducts in the ration considered in the feeding of cows (Table 10) and growing bulls (Table 11). The highest WF per kilogram of edible protein can be calculated for growing and fattening pigs and beef cattle with low animal yields, followed by laying hens (see Table 13).

\subsection{Carbon footprints}

Carbon footprints are defined as the total amount of GHG emissions along the human food supply chain. These are defined depending on their GHG potential: 1 for $\mathrm{CO}_{2}, 23$ for $\mathrm{CH}_{4}$ and 296 for $\mathrm{N}_{2} \mathrm{O}$ (IPCC, 2006). The supply chain includes the plant production, including cultivation, harvest, treatment and storage, feed preparation, feeding of foodproducing animals, preparation of food and, finally, distribution to market and households.

Beginning with once- and twice-yearly studies in 19982000, about 20 annual studies were published in the last years (Avadi and Freon, 2013). The studies dealt with calculations of CF for nearly all types of food of animal origin (see summary by Lesschen et al., 2011).

Results of CF calculations for food of animal origin depend on many influencing factors such as animal species and categories, animal yields and endpoints of animal production. From nutritional and scientific points of view, edible protein seems to be the most favorable reference value (see Flachowsky and Kamphues, 2012).

Table 14 demonstrates some important emission sources and steps to calculate emissions per cow and year or per kilogram of milk. The values per cow or per kilogram of milk depend mainly on the levels of emissions and on the milk yield. The calculation shows that in this case about two-thirds of emissions come from methane.

The $\mathrm{CO}_{2}$ emission directly from the animals can be considered as emission neutral. $\mathrm{CO}_{2}$ is fixed through photosynthesis of plants and excreted by the animals as a result of animal metabolism. Nevertheless, the $\mathrm{CO}_{2}$ emission must be observed along the whole food chain and assessments must be based on the burning of fossil carbon during feed production and land use changes (Caffrey and Veal, 2013; Hergoualch and Verchot, 2011; Kim et al., 2009).

Methane is emitted under anaerobic conditions from the enteric fermentation in the digestive tract of animals, mainly in the rumen, but also during manure management. Details about the enteric methane production and reduction potential are described in many papers (e.g., Bannink et al., 2008; Beauchemin et al., 2009) and prediction equations are given (e.g., Ellis et al., 2010; Montes et al., 2013). The methane emissions from manure management are generally not directly associated with animals, but the emissions can be considerably high (Montes et al., 2013), especially if the excreta are stored under anaerobic conditions.

Animals do not excrete $\mathrm{N}_{2} \mathrm{O}$ directly, but it can be formed in manure depending on the storage conditions and following land application (e.g., Flachowsky and Brade, 2007; Montes et al., 2013). Nitrous oxide is mainly produced in soils through microbial nitrification (the oxidation of ammonium $\left[\mathrm{NH}_{4}^{+}\right]$to nitrate $\mathrm{NO}_{3}^{-}$) and denitrification (reduction of $\mathrm{NO}_{3}^{-}$to $\mathrm{N}_{2}$; Stevens et al., 1997). These microbial processes depend on temperature, moisture content and oxidation status of the environment. More details about $\mathrm{N}_{2} \mathrm{O}$ production and emission from the soil were described by many authors and will not be considered further in this paper (e.g., Bessou et al., 2010; Lampe et al., 2006; Schmeer et al., 2014; van Groenigen et al., 2005; Weisskopf et al., 2010). 
Table 11. Model calculation of water footprint (WF) for beef cattle from 150 to $550 \mathrm{~kg}$ body weight depending on the daily weight gain and coproducts in feeding.

\begin{tabular}{|c|c|c|c|c|c|c|c|c|c|}
\hline $\begin{array}{l}\text { Beef cattle } \\
\text { (weight } \\
\text { gain } g \text { day }^{-1} \text { ) }\end{array}$ & $\begin{array}{r}\mathrm{DM}^{\mathrm{a}} \\
\text { intake } \\
\left(\mathrm{kg} \mathrm{day}^{-1}\right)\end{array}$ & $\begin{array}{r}\text { Roughage } \\
\text { part } \\
(\% \text {; DM base })\end{array}$ & $\begin{array}{r}\text { Concentrate } \\
\text { intake } \\
\left(\mathrm{kg} \mathrm{DMd}^{-1}\right)\end{array}$ & $\begin{array}{r}\text { Coproducts } \\
\text { in concentrate } \\
(\%)\end{array}$ & $\begin{array}{r}\text { Coproduct } \\
\text { intake } \\
\left(\mathrm{kg} \mathrm{DM} \mathrm{d}^{-1}\right)\end{array}$ & $\begin{array}{r}\text { Water intake } \\
\text { via feed }^{\mathrm{b}} \\
\left(\mathrm{Ld}^{-1}\right)\end{array}$ & $\begin{array}{r}\mathrm{WF} \\
(\mathrm{LkgBW} \\
\left.\text { gain }^{-1}\right)\end{array}$ & $\begin{array}{r}\mathrm{WF} \\
(\mathrm{Lkg} \\
\left.\text { beef }^{-1}\right)\end{array}$ & $\begin{array}{r}\mathrm{WF} \\
\left(\mathrm{m}^{3} \mathrm{~kg} \mathrm{edible}^{-1}\right. \\
\left.\text { protein }^{-1}\right)\end{array}$ \\
\hline 500 & 6.5 & 95 & 0.3 & $100^{c}$ & 0.3 & 1160 & 2320 & 4640 & 48.8 \\
\hline 1000 & 7.0 & 80 & 1.3 & $75^{\mathrm{d}}$ & 1.0 & 1420 & 1420 & 1420 & 15.1 \\
\hline 1500 & 7.5 & 65 & 2.45 & $50^{\mathrm{e}}$ & 1.2 & 2200 & 1470 & 980 & 10.4 \\
\hline
\end{tabular}

${ }^{a}$ Dry matter. ${ }^{b}$ WF of feed by Mekonnen and Hoekstra (2010): $1048 \mathrm{~L} \mathrm{~kg} \mathrm{concentrate}^{-1} ; 203 \mathrm{~L} \mathrm{~kg} \mathrm{roughage}^{-1}$; see Table $4 .{ }^{\mathrm{c}}$ Includes $50 \%$ wheat bran; $50 \%$ dried sugar beet pulp. ${ }^{\mathrm{d}}$ Includes $25 \%$ cereal grain; $30 \%$ wheat bran; $30 \%$ sugar beet pulp; $10 \%$ rapeseed meal; $5 \%$ soybean meal. ${ }^{\mathrm{e}} 50 \%$ cereal grains; $12.5 \%$ wheat bran; $12.5 \%$ dried sugar beet pulp; $15 \%$ rapeseed meal; $10 \%$ soybean meal.

Table 12. Water footprint $\left(\mathrm{L} \mathrm{kg}^{-1}\right)$ of animal products in various publications.

\begin{tabular}{lrr}
\hline $\begin{array}{l}\text { Animal } \\
\text { products }\end{array}$ & $\begin{array}{r}\text { Hoekstra } \\
(2010)\end{array}$ & $\begin{array}{r}\text { Mekonnen and } \\
\text { Hoekstra }(2012)\end{array}$ \\
\hline Milk & 1000 & 1020 \\
Beef & 15500 & 15415 \\
Pork & 4800 & 5988 \\
Chicken & 3900 & 4325 \\
Eggs & 3300 & 3265 \\
\hline
\end{tabular}

The public interest in $\mathrm{CF}$ is discussed in the context of global warming and possible climate changes (IPCC, 2006, 2014). Results of CF calculation for foods of animal origin depend on many influencing factors such as animal species and categories, animal feeding and yields, and endpoints of animal production (see Table 15). Feeding may influence the $\mathrm{CF}$ of food of animal origin. In the case of ruminants, higher animal yields require higher amounts of concentrate. The proportion of coproducts (e.g., Ahlgrimm et al., 2000; Ertl et al., 2015; Makkar, 2012) used in animal nutrition has not only nutritional implications, but it also affects the results of calculations on land use (Vandehaar, 1998). There are large differences in protein yield per animal per day or per kilogram of body weight and day depending on animal species and categories as well as on their performances and the fractions considered as edible.

Fossil energy inputs are not considered in these calculations. Frorip et al. (2012) analyzed the fossil energy consumption in animal production on the basis of farm studies and calculated an energy input per kilogram of milk of 5.4 MJ. In the literature review of the same authors, 14 references showed a range between 1.6 and $7 \mathrm{MJ} \mathrm{kg}^{-1}$ milk. These disparate values show the difficulties of considering these and further inputs during calculations of CF.

Table S6 shows the highest protein yields per kilogram of body weight for growing broilers as well as for laying and lactating animals and the lowest values for growing and fattening ruminants. Based on those values, emissions per kilogram of edible protein are given in Table 15. Higher por- tions of edible fractions or higher protein content may increase the protein yield and reduce the CF per product. At high levels of performance there are remarkable differences in $\mathrm{CO}_{2}$ emissions due to a human consumption of $1 \mathrm{~g}$ protein from food of animal origin (eggs and meat from poultry $<$ pork $<$ milk $<$ beef).

\section{Improvement of protein supply for humans and animals}

Apart from intensification of plant and animal production, there are also other possibilities to improve the protein supply for humans and animals. These are alternative protein sources for food and feed (see in Sects. 5.1 until 5.5), as well as changing eating patterns (see in Sect. 5.6) or reducing food losses (see in Sect. 5.7).

\subsection{Aquaculture}

Aquaculture, although already having a long tradition, is a rapidly growing sector of production of food protein of animal origin. Recently, some authors tried to determine CF for various forms of aquaculture. Mungkung et al. (2013) carried out a case study of combined aquaculture systems for carp and tilapia. The system studied included fingerling production in hatcheries, fish rearing in cages and transport of feed and harvested fish to markets. Avadi and Freon (2013) reviewed 16 life cycle assessment (LCA) studies applied to fisheries and considered the following aspects in their comparison: scope and system boundaries, functional unit allocation strategies for coproducts, conventional and fisheryspecific impact categories, fuel use, impact assessment methods, level of detail of inventories, normalization of results, and sensitivity analysis. Fishery-specific impact categories and fuel use in fishing operation were identified as the main contributors to environmental impact. Nijdam et al. (2012) analyzed 18 studies for seafood from fisheries and 11 from aquaculture, and they compared results with data of land animals (Table 16). The authors summarized CF between 1 and 86 for seafood from fisheries and 3 and $15 \mathrm{~kg} \mathrm{CO}$ eq. per kilogram of product for seafood from aquaculture. 
Table 13. Influence of animal species, categories and performances on yield of edible protein and water footprint (WF) per kilogram of edible protein.

\begin{tabular}{|c|c|c|c|c|c|c|c|c|}
\hline \multirow{6}{*}{ 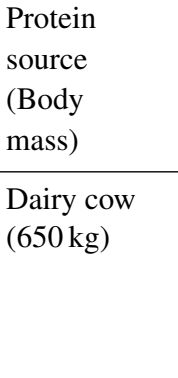 } & \multicolumn{2}{|c|}{$\begin{array}{r}\text { Performance } \\
\text { (per } \\
\text { day) }\end{array}$} & $\begin{array}{r}\text { Dry } \\
\text { matter } \\
\text { intake } \\
\left(\mathrm{kg} \mathrm{day}^{-1}\right)\end{array}$ & $\begin{array}{r}\text { Roughage } \\
\text { part } \\
\left(\mathrm{DM}^{\mathrm{c}}\right. \\
\text { basis, \% })^{3}\end{array}$ & $\begin{array}{r}\text { Edible } \\
\text { protein } \\
\text { yield } \\
\left(\mathrm{g} \mathrm{day}^{-1}\right)^{\mathrm{d}}\end{array}$ & $\begin{array}{r}\text { Water } \\
\text { need for } \\
\text { feed } \\
\left(\mathrm{m}^{3} \text { day }^{-1}\right)^{\mathrm{e}}\end{array}$ & $\begin{array}{r}\text { WF } \\
\left(\mathrm{m}^{3} \mathrm{~kg}\right. \\
\left.\text { product }^{-1}\right)^{\mathrm{f}}\end{array}$ & $\begin{array}{r}\mathrm{WF} \\
\left(\mathrm{m}^{3} \mathrm{~kg}\right. \\
\text { edible } \\
\left.\text { protein }^{-1}\right)\end{array}$ \\
\hline & 2 & kg milk & 8 & 100 & 67 & 1.62 & 0.82 & 24.6 \\
\hline & 5 & kg milk & 10 & 95 & 163 & 2.55 & 0.52 & 16.0 \\
\hline & 10 & kg milk & 12 & 90 & 323 & 3.45 & 0.35 & 10.9 \\
\hline & 20 & kg milk & 16 & 75 & 646 & 6.63 & 0.34 & 10.5 \\
\hline & 40 & $\mathrm{~kg}$ milk & 25 & 50 & 1292 & 15.64 & 0.40 & 12.3 \\
\hline \multirow{4}{*}{$\begin{array}{l}\text { Dairy goat } \\
(60 \mathrm{~kg})\end{array}$} & 0.5 & kg milk & 1 & 100 & 17 & 0.20 & 0.40 & 11.8 \\
\hline & 1 & kg milk & 1.5 & 90 & 34 & 0.43 & 0.43 & 12.6 \\
\hline & 2 & kg milk & 2 & 80 & 68 & 0.75 & 0.38 & 11.0 \\
\hline & 5 & kg milk & 2.5 & 50 & 170 & 1.57 & 0.31 & 9.3 \\
\hline \multirow{4}{*}{$\begin{array}{l}\text { Beef cattle } \\
(350 \mathrm{~kg})\end{array}$} & 200 & $\mathrm{~g} \mathrm{ADG}^{\mathrm{a}}$ & 6.0 & 100 & 19 & 1.22 & 6.20 & 64.7 \\
\hline & 500 & g ADG & 6.5 & 95 & 48 & 1.60 & 3.26 & 34.0 \\
\hline & 1000 & $\mathrm{~g}$ ADG & 7.0 & 85 & 95 & 2.30 & 2.35 & 24.7 \\
\hline & 1500 & g ADG & 7.5 & 70 & 143 & 3.43 & 2.33 & 24.5 \\
\hline \multirow{4}{*}{$\begin{array}{l}\text { Growing/ } \\
\text { fattening pig } \\
(80 \mathrm{~kg})\end{array}$} & 200 & g ADG & 1.5 & 30 & 18 & 1.18 & 6.00 & 66.1 \\
\hline & 500 & $\mathrm{~g}$ ADG & 1.8 & 20 & 45 & 1.58 & 3.22 & 35.8 \\
\hline & 700 & $\mathrm{~g}$ ADG & 2 & $10 /$ & 63 & 1.93 & 2.81 & 31.3 \\
\hline & 1000 & $\mathrm{~g}$ ADG & 2.2 & 0 & 90 & 2.31 & 2.36 & 26.1 \\
\hline \multirow{3}{*}{$\begin{array}{l}\text { Chicken for } \\
\text { fattening } \\
(1.5 \mathrm{~kg})\end{array}$} & 20 & g ADG & 0.06 & 15 & 2.4 & 0.055 & 2.75 & 23.0 \\
\hline & 40 & $\mathrm{~g}$ ADG & 0.07 & 10 & 4.8 & 0.068 & 1.75 & 14.4 \\
\hline & 60 & $\mathrm{~g} \mathrm{ADG}$ & 0.08 & 0 & 7.2 & 0.084 & 1.45 & 11.8 \\
\hline \multirow{4}{*}{$\begin{array}{l}\text { Laying hen } \\
(1.8 \mathrm{~kg})\end{array}$} & 20 & $\% \mathrm{LP}^{\mathrm{b}}$ & 0.09 & 30 & 1.4 & 0.071 & 7.20 & 51.4 \\
\hline & 50 & $\%$ LP & 0.10 & 20 & 3.4 & 0.088 & 3.60 & 26.5 \\
\hline & 70 & $\% \mathrm{LP}$ & 0.11 & 10 & 4.8 & 0.106 & 3.15 & 22.5 \\
\hline & 90 & $\%$ LP & 0.12 & 0 & 6.2 & 0.126 & 2.90 & 20.8 \\
\hline
\end{tabular}

a Average daily gain. ${ }^{\mathrm{b}}$ Laying performance. ${ }^{\mathrm{c}}$ Dry matter. ${ }^{\mathrm{d}}$ See Table S2. ${ }^{\mathrm{e}}$ WF of feed by Mekonnen and Hoekstra (2010): 1048 L kg concentrate ${ }^{-1}$; $203 \mathrm{~L} \mathrm{~kg} \mathrm{roughage}{ }^{-1}$. ${ }^{\mathrm{f}}$ Water for management (drinking and cleaning) is assumed to be about $2 \%$ of water for feed.

Table 14. Calculation of emissions per cow and year $\left(650 \mathrm{~kg}\right.$ body weight, $8000 \mathrm{~kg}$ milk year $^{-1}$, one calf per year; Dämmgen and Haenel, 2008).

\begin{tabular}{lrrrr}
\hline Source of emissions & & \multicolumn{3}{c}{ Emissions } \\
\cline { 3 - 5 } & $\left(\mathrm{kg} \mathrm{cow}^{-1}\right.$ year $\left.^{-1}\right)$ & $\mathrm{CO}_{2}$ & $\mathrm{CH}_{4}$ & $\mathrm{~N}_{2} \mathrm{O}$ \\
\hline Fertilizer & 210 & 5.5 & 1.1 \\
Feed & & 83 & & 1.2 \\
Transport, treatment & 43 & & \\
Rumen fermentation & & 119 & \\
Fermentation of excrement management & & 19 & 0.9 \\
Emissions from soil & & 336 & 143 & 5 \\
Total & $\left(\mathrm{kg} \mathrm{cow}^{-1}\right)$ & 336 & 3290 & 1500 \\
$\mathrm{CO}_{2}$ equivalents of emission & $\left(\mathrm{kg} \mathrm{cow}^{-1}\right.$ year $\left.^{-1}\right)$ & 65 & 29 \\
$\mathrm{CO}_{2}$ equivalents & $\left(\mathrm{g} \mathrm{kg} \mathrm{milk}^{-1}\right)^{\mathrm{b}}$ & 5200 & \\
& & 650 & \\
\hline
\end{tabular}

${ }^{a}$ No land use change. ${ }^{b}$ Without calf and heifer. 
Table 15. Influence of animal species, categories and performances on emissions and footprints (per kilogram of edible protein; own calculations based on data from Flachowsky and Kamphues, 2012).

\begin{tabular}{|c|c|c|c|c|c|c|c|c|}
\hline \multirow{2}{*}{$\begin{array}{l}\text { Protein } \\
\text { source } \\
\text { (Body weight) }\end{array}$} & \multirow{2}{*}{\multicolumn{2}{|c|}{$\begin{array}{r}\text { Performance } \\
\text { per day }\end{array}$}} & \multirow{2}{*}{$\begin{array}{r}\mathrm{N} \text { excretion } \\
(\% \text { of } \\
\text { intake })\end{array}$} & \multirow{2}{*}{$\begin{array}{r}\text { Methane } \\
\text { emission } \\
\left(\mathrm{g} \mathrm{day}^{-1}\right)^{\mathrm{c}}\end{array}$} & \multicolumn{4}{|c|}{ Emissions $\left(\mathrm{g} \mathrm{kg}_{\text {protein }}{ }^{-1}\right)$} \\
\hline & & & & & $\mathrm{P}$ & $\mathrm{N}$ & $\mathrm{CH}_{4}{ }^{\mathrm{c}}$ & $\mathrm{CO}_{2 \mathrm{eq}}$ \\
\hline \multirow{3}{*}{$\begin{array}{l}\text { Dairy cow } \\
(650 \mathrm{~kg})\end{array}$} & 10 & $\mathrm{~kg}$ milk & 75 & 310 & 0.10 & 0.65 & 1.0 & 30 \\
\hline & 20 & $\mathrm{~kg}$ milk & 70 & 380 & 0.06 & 0.44 & 0.6 & 16 \\
\hline & 40 & kg milk & 65 & 520 & 0.04 & 0.24 & 0.4 & 12 \\
\hline \multirow{2}{*}{$\begin{array}{l}\text { Dairy goat } \\
(60 \mathrm{~kg})\end{array}$} & 2 & $\mathrm{~kg}$ milk & 75 & 50 & 0.08 & 0.5 & 0.8 & 20 \\
\hline & 5 & $\mathrm{~kg}$ milk & 65 & 60 & 0.04 & 0.2 & 0.4 & 10 \\
\hline \multirow{3}{*}{$\begin{array}{l}\text { Beef cattle } \\
(350 \mathrm{~kg})\end{array}$} & 500 & $\mathrm{~g}^{\mathrm{a}}$ & 90 & 170 & 0.30 & 2.3 & 3.5 & 110 \\
\hline & 1000 & $\mathrm{~g}^{\mathrm{a}}$ & 84 & 175 & 0.18 & 1.3 & 1.7 & 55 \\
\hline & 1500 & $\mathrm{~g}^{\mathrm{a}}$ & 80 & 180 & 0.14 & 1.0 & 1.2 & 35 \\
\hline \multirow{3}{*}{$\begin{array}{l}\text { Growing/ } \\
\text { fattening pig } \\
(80 \mathrm{~kg})\end{array}$} & 500 & $\mathrm{~g}^{\mathrm{a}}$ & 85 & 5 & 0.20 & 1.0 & 0.12 & 16 \\
\hline & 700 & $\mathrm{~g}^{\mathrm{a}}$ & 80 & 5 & 0.12 & 0.7 & 0.08 & 12 \\
\hline & 900 & $\mathrm{~g}^{\mathrm{a}}$ & 75 & 5 & 0.09 & 0.55 & 0.05 & 10 \\
\hline \multirow{2}{*}{$\begin{array}{l}\text { Broiler } \\
(1.5 \mathrm{~kg})\end{array}$} & 40 & $\mathrm{~g}^{\mathrm{a}}$ & 70 & Traces & 0.04 & 0.35 & 0.01 & 4 \\
\hline & 60 & $\mathrm{~g}^{\mathrm{a}}$ & 60 & & 0.03 & 0.25 & 0.01 & 3 \\
\hline \multirow{3}{*}{$\begin{array}{l}\text { Laying hen } \\
(1.8 \mathrm{~kg})\end{array}$} & 50 & $\%^{\mathrm{b}}$ & 80 & Traces & 0.12 & 0.6 & 0.03 & 7 \\
\hline & 70 & $\%^{b}$ & 65 & & 0.07 & 0.4 & 0.02 & 5 \\
\hline & 90 & $\%^{\mathrm{b}}$ & 55 & & 0.05 & 0.3 & 0.02 & 3 \\
\hline
\end{tabular}

${ }^{a}$ Daily weight gain. ${ }^{b}$ Laying performance. ${ }^{c} \mathrm{CH}_{4}$ emission depending on composition of diet.

Table 16. Carbon footprints of protein of food of animal origin according to several life cycle assessment studies summarized by Nijdam et al. (2012).

\begin{tabular}{llrr}
\hline Protein sources & Number of studies & $\mathrm{kg} \mathrm{CO}_{2 \text { eq. }} \mathrm{kg} \mathrm{product}^{-1}$ & $\mathrm{~kg} \mathrm{CO}_{2 \text { eq. }} \mathrm{kg} \mathrm{protein}^{-1}$ \\
\hline Cow's milk & $(n=14)$ & $1-2$ & $28-43$ \\
Beef, intensive system & $(n=11)$ & $9-42$ & $45-210$ \\
Meadow, suckler herds & $(n=8)$ & $23-52$ & $114-250$ \\
Extensive pastoral systems & $(n=4)$ & $12-129$ & $58-643$ \\
Mutton and lamb & $(n=5)$ & $10-150$ & $51-750$ \\
Pork & $(n=11)$ & $4-11$ & $20-55$ \\
Poultry meat & $(n=5)$ & $2-6$ & $10-30$ \\
Eggs & $(n=5)$ & $2-6$ & $15-42$ \\
Seafood from fisheries & $(n=18)$ & $1-86$ & $4-540$ \\
Seafood from aquaculture & $(n=11)$ & $3-15$ & $4-75$ \\
\hline
\end{tabular}

These authors and Avadi and Freon (2013) define the need for standardization of fishery LCAs to improve research and enhance further studies on sustainability of seafood and fishery-based agrifood.

\subsection{Insects}

Apart from milk, meat, eggs and fish, there are also other sources of protein of animal origin, such as wild animals and insects, consumed by humans. Nothing is known about CF of food from wild animals.
Insects and their larvae are used as food in many countries. The most commonly eaten insect groups are the Coleoptera (beetles), Lepidoptera (caterpillars of butterflies and moths), Hymenoptera (bees, wasps, ants), Orthoptera (grasshoppers, locusts, crickets, termites), Hemiptera (cicadas, leaf and plant hoppers, true bugs, scale insects), Odonata (dragonflies) and Diptera (flies) (EFSA, 2015). They are rich in protein (5 to about $80 \%$; Table 17) and contain considerable amounts of fat (10-50\% of DM; Makkar et al., 2014; Sanchez-Muros et al., 2014; van Huis, 2013). More than 2 billion people worldwide include processed insects in their diets (van Huis, 2013). Experts (e.g., van Huis, 2013) believe 
that in total about 1900 insect species are used as food and feed.

The feed conversion of insects is estimated to be better than that of other animals, and thus their CF is expected to be lower (e.g., Oonincx and de Boer, 2012; Oonincx et al., 2010). However, more research in these fields (e.g., Lundy and Parrella, 2015) and also concerning feeding and feed supplementation of insects is required (van Huis, 2013). Another topic would be the still missing public acceptance of insect-based food of animal origin in some regions of the world (EFSA, 2015).

\subsection{Cultured "lab-grown" meat}

The dream to produce "cultured meat", also called "cell cultured", "synthetic" or "clean meat", is very old. In 1931, Winston Churchill was very hopeful that we should, 50 years hence, escape the absurdity of growing a whole chicken in order to eat the breast wing by growing these parts separately under a suitable medium. About 75 years later, Bill Gates concluded that remaking meat was one sector of food industry that was ripe for innovation and growth. However, we are still waiting for a real progress in these processes of creating lab-grown or "in vitro" meat. Presently, about 30 laboratories around the world are conducting research on cultured meat. In cultures with an adequate growth medium, it could be achieved that bovine skeletal muscle stem cells managed to produce beef with the same nutritional value as livestock and could therefore replace protein of animal origin (Post, 2014a, b). Sheep, pig, turkey and fish muscle cells have also been identified for the same purposes (Benjaminson et al., 2002; Dodson et al., 1988, 1997). Protein synthesis by cultured skeletal muscle cells, in theory, should be very efficient.

Apart from further investigations for optimization of protein and fat content of cultured meat, more studies concerning psychological obstacles and public acceptance are necessary and complete LCAs for all these future ways to produce valuable food proteins are needed.

\section{4 "Simulated" food}

Foods of plant origin with a high protein concentration such as grain-based products, leguminous vegetables, nuts or extracted proteins from leaves of plants may replace animal protein in the human diet (see also Sect. 5.5). There exist some alternatives and initiatives to replace protein of animal origin with other ways to produce similar products (e.g., soy milk, tofu, rice milk). Mostly, such food is processed from valuable protein sources of plant origin (e.g., soybean, wheat, rice, maize, barley, pea, sorghum, lupine and chickpea). Some authors tried to develop new analogue meat and milk products by combining proteins from various plant sources (Aiking, 2011; Day, 2013). The ideas about such developments are not new, but the public acceptance is still limited.

\subsection{Single-cell proteins, algae and further new food and feed sources}

Apart from food of animal origin (see above), single cell proteins may also be a further alternative to meet the protein and amino acid requirements of humans and provide them with a high enjoyment value of the foods (Anupama and Ravindra, 2000; Zepka et al., 2010).

Algae are considered as a potential food and feed reserve (e.g., Tredici, 2010). They are rich in protein (40-70\% in DM) and fat (40-45\%) and have a long history of use in human and animal nutrition (Bux and Christi, 2016). However, due to the high production costs as well as difficulties incorporating algal material into palatable food preparations, the use of algal protein is still in its infancy (Becker, 2007). However, Tredici (2010) believes that the photobiology of microalgae mass culture can be significantly improved and a higher yield can be achieved. Guccione et al. (2014) studied the yield potential of various Chlorella strains and concluded that there are large differences between them. The highest yields, extrapolated to one hectare and year were $16 \mathrm{t}$ of protein and $11 \mathrm{t}$ of lipids.

Yeasts have been used by humans for thousands of years in traditional fermentation processes, but also as sources of proteins ( $>45 \%$ protein in DM; Bekatorou et al., 2006) and food and feed additives. They may utilize various carbohydrates, but the various processes are expensive in substrate input and costs.

Proteins extracted from leaves (termed leaf protein concentrates) may also contribute as protein sources for humans and animals (e.g., Dewan et al., 2007; Mendieta-Araica et al., 2011).

Windisch et al. (2013) analyzed the more effective use of known feed sources, such as seed meals by reduction or inhibition of antinutritive substances (e.g., glucosinolates in rapeseed; aflatoxins in peanut meal; gossypol in cottonseed meal) or the exploitation of new feeds (such as Jatropha curcas through elimination of various toxins). More effective utilization of coproducts resulting from agriculture (e.g., cereal straw, sugar beet leaves) and biofuel production (e.g., Makkar, 2012) can also be considered as feed resources.

\subsection{Change of eating pattern}

Apart from food of animal origin and other food sources (see above), there are also further alternatives to meet the protein and amino acid requirements of humans and to have a high enjoyment value of the foods. These include changing eating patterns, reducing food losses along the food production chain and developing simulated food from processed plant proteins or cultured muscle cells.

Changing eating patterns (Guyomard et al., 2012) and consuming less or no livestock products, especially meat, are often seen as possible solutions to reduce the environmental impact of animal agriculture (Baroni et al., 2007; Pimentel 
Table 17. Examples for the variation in protein content of various insect species (\% of dry matter; summarized by EFSA, 2015; Flachowsky and Klüß, 2015).

\begin{tabular}{lrr}
\hline References & Numbers of investigated species & Crude protein \\
\hline Bukkens (1997) & 50 & $7.5-79.6$ \\
Finke (2002) & 75 & $22.5-80.0$ \\
St-Hilaire et al. (2007) & Black soldier fly (prepupa) & 43.6 \\
& Housefly (pupa) & 70.4 \\
Grabowski et al. (2008) & 17 & $40.0-86.6$ \\
Oonincx and de Boer (2012) & 6 & $38.3-76.1$ \\
Rumpold and Schluter (2013) & $234^{*}$ & $4.9-74.8$ \\
Sanchez-Muros et al. (2014) & 72 & $9.5-70.1$ \\
Makkar et al. (2014) & Black soldier fly larva (1-5)* & $41.1-43.6$ \\
& Housefly maggot meal (19-29) & $42.3-60.4$ \\
& Mealworm (2-10) & $47.2-60.3$ \\
& Grasshopper meal (7-9) & $29.2-65.9$ \\
& House cricket (2-4) & $55.0-67.2$ \\
& Silkworm pupa meal (6-11) & $51.6-70.6$ \\
\hline
\end{tabular}

* Number of samples.

and Pimentel, 2003) and to reduce the per capita LF (Flachowsky et al., 2017; Peters et al., 2007).

\subsection{Reduction in food losses and waste}

The issue of global food losses and waste has recently received much attention. According to FAO (2011), about onethird of food produced for human consumption globally about 1.3 billion $t$ of edible food per year - is lost or wasted. This amount is equal to about $24 \%$ of all calories currently produced for human consumption. In developing countries food waste and losses occur mainly at the early stages of the food value chain; in medium- or high-income countries food is wasted or lost mainly at later stages of the food chain (FAO, 2011). Reduction of food waste and loss is essential to improve food security, sustainability of food production and to reduce the environmental footprints, such as LF, WF and CF of food systems (Blanke, 2015; Parfitt et al., 2010). A reduction of losses can be easily achieved by adequate management measurements. LCAs of food waste also demonstrate the environmental burdens of the waste elimination (Thyberg and Tonjes, 2017).

\section{Conclusions}

In conclusion, food security and optimal human nutrition taking into account limited resources, increased emissions and expected climate change can be considered as the top challenge for all those dealing with feed and food production and nutrition. We conclude that more work is needed to understand the values underlying different approaches to food sustainability aspects, such as harmonization of data collection and calculation methods. In the future, footprints for land (LF), water (WF) and GHG emissions (CF) could be very helpful tools for strategic decisions. Apart from life cycle assessments for traditional ways of food production, adequate studies applying accepted methods are required for enhancing research on alternative methods of food production.

More food for more people with less and limited resources available and at the same time lower emissions is a big challenge for all those working along the whole food production chain and thereby dealing with plant or animal breeding and cultivation.

Data availability. No data sets were used in this article.

Supplement. The supplement related to this article is available online at: https://doi.org/10.5194/aab-61-17-2018-supplement.

Competing interests. The authors declare that they have no conflict of interest.

Edited by: Manfred Mielenz

Reviewed by: two anonymous referees

\section{References}

Ahlgrimm, H.-J., Böhme, H., Bramm, A., Dämmgen, U., Flachowsky, G., Höppner, F., Rogasik, J., and Sohler, S.: Bewertung von Verfahren der ökologischen und konventionellen landwirtschaftlichen Produktion im Hinblick auf den Energieeinsatz und bestimmte Schadgasemissionen: Studie als Sondergutachten im Auftrag des Bundesministeriums für Ernährung, Landwirtschaft und Forsten, Bonn, edited by: Bockisch, F. J., Landbauforschung Völkenrode Sonderheft 211, Braunschweig, 206 pp., 2000 
Aiking, H.: Future protein supply, Trends Food Sci. Tech., 22, 112120, https://doi.org/10.1016/j.tifs.2010.04.005, 2011.

Aiking, H.: Protein production: planet, profit, plus people?, Am. J. Clin. Nutr., 100, 483-489, https://doi.org/10.3945/ajcn.113.071209, 2014.

Anupama, P. R. and Ravindra, P.: Value-added food: single cell protein, Biotechnol. Adv., 18, 459-479, 2000.

Avadi, A. and Freon, P.: Life cycle assessment of fisheries: a review for fisheries scientists and managers, Fish Res., 143, 21-38, https://doi.org/10.1016/j.fishres.2013.01.006, 2013.

Bannink, A., France, J., Lopez, S., Gerrits, W. J. J., Kebreab, E., Tamminga, S., and Dijkstra, J.: Modelling the implications of feeding strategy on rumen fermentation and functioning of the rumen wall, Anim. Feed Sci. Tech., 143, 3-26, https://doi.org/10.1016/j.anifeedsci.2007.05.002, 2008.

Baroni, L., Cenci, L., Tettamanti, M., and Berati, M.: Evaluating the environmental impact of various dietary patterns combined with different food production systems, Eur. J. Clin. Nutr., 61, 279-286, https://doi.org/10.1038/sj.ejcn.1602522, 2007.

Bauer, J., Biolo, G., Cederholm, T., Cesari, M., Cruz-Jentoft, A. J., Morley, J. E., Phillips, S., Sieber, C., Stehle, P., Teta, D., Visvanathan, R., Volpi, E., and Boirie, Y.: Evidencebased recommendations for optimal dietary protein intake in older people: a position paper from the PROT-AGE Study Group, J. Am. Med. Dir. Assoc., 14, 542-559, https://doi.org/10.1016/j.jamda.2013.05.021, 2013.

Beauchemin, K. A., McAllister, T. A., and McGinn, S. M.: Dietary mitigation of enteric methane from cattle, CAB Reviews: Perspectives in Agriculture, Veterinary Science, Nutrition and Natural Resources, 4, 1-18, 2009.

Becker, E. W.: Micro-algae as a source of protein, Biotechnol. Adv., 25, 207-210, https://doi.org/10.1016/j.biotechadv.2006.11.002, 2007.

Bekatorou, A., Psarianos, C., and Koutinas, A. A.: Production of food grade yeasts, Food Technol. Biotech., 44, 407-415, 2006.

Benjaminson, M. A., Gilchriest, J. A., and Lorenz, M.: In vitro edible muscle protein production system (MPPS): Stage 1, fish, Acta Astronaut., 51, 879-889, https://doi.org/10.1016/S00945765(02)00033-4, 2002.

Bessou, C., Mary, B., Leonard, J., Roussel, M., Grehan, E., and Gabrielle, B.: Modelling soil compaction impacts on nitrous oxide emissions in arable fields, Eur. J. Soil Sci., 61, 348-363, https://doi.org/10.1111/j.1365-2389.2010.01243.x, 2010.

Blanke, M.: Challenges of reducing fresh produce waste in Europe - from farm to fork, Agriculture, 5, 389-399, 2015.

Boonen, R., Aerts, S., and De Tavernier, J.: Which sustainability suits you?, in: Climate Change and Sustainable Development, Wageningen Academic Publishers, the Netherlands, 4348, 2012.

Brooks, P. H., Russell, S. J., and Carpenter, J. L.: Water intake of weaned piglets from 3 to 7 weeks old, Vet. Rec., 115, 513-515, 1984.

Bukkens, S. G. F.: The nutritional value of edible insects, Ecol. Food Nutr., 36, 287-319, 1997.

Bux, F. and Christi, Y.: Algae Biotechnology - Products and Processes, Springer International Publishing, Cham, Switzerland, 344 pp., 2016.
Caffrey, K. R. and Veal, M. W.: Conducting an agricultural life cycle assessment: challenges and perspectives, Sci. World J., 2013, 472431, https://doi.org/10.1155/2013/472431, 2013.

Cassidy, E. S., West, P. C., Gerber, J. S., and Foley, J. A.: Redefining agricultural yields: from tonnes to people nourished per hectare, Environ. Res. Lett., 8, 034015, https://doi.org/10.1088/17489326/8/3/034015, 2013.

Castle, M. E. and Thomas, T. P.: Water-intake of British Friesian Cows on rations containing various forages, Anim. Prod., 20, 181-189, 1975.

D'Mello, J. P. F.: Amino Acids in Human Nutrition and Health, CABI, Wallingford, 584 pp., 2012.

Dahlborn, K., Akerlind, M., and Gustafson, G.: Water intake by dairy cows selected for high or low milk-fat percentage when fed two forage to concentrate ratios with hay or silage, Swed. J. Agr. Res., 28, 167-176, 1998.

Dämmgen, U. and Haenel, H. D.: Emissions of Greenhouse Gases and Gaseous Air Pollutants - a Challenge for Animal Nutrition, Proceedings of the Society of Nutrition Physiology, Göttingen, Germany, 163-167, 2008.

Day, L.: Proteins from land plants - potential resources for human nutrition and food security, Trends Food Sci. Tech., 32, 25-42, https://doi.org/10.1016/j.tifs.2013.05.005, 2013.

de Vries, M. and de Boer, I. J. M.: Comparing environmental impacts for livestock products: a review of life cycle assessments, Livest. Sci., 128, 1-11, https://doi.org/10.1016/j.livsci.2009.11.007, 2010.

Dewan, P., Kaur, I., Chattopadhya, D., Faridi, M. M. A., and Agarwal, K. N.: A pilot study on the effects of curd (dahi) \& leaf protein concentrate in children with protein energy malnutrition (PEM), Indian J. Med. Res., 126, 199-203, 2007.

Dodson, M. V., Mathison, B. A., Brannon, M. A., Martin, E. L., Wheeler, B. A., and Mcfarland, D. C.: Comparison of ovine and rat muscle-derived satellite cells - response to insulin, Tissue Cell, 20, 909-918, https://doi.org/10.1016/0040-8166(88)90032$8,1988$.

Dodson, M. V., Vierck, J. L., Hossner, K. L., Byrne, K., and McNamara, J. P.: The development and utility of a defined muscle and fat co-culture system, Tissue Cell, 29, 517-524, https://doi.org/10.1016/S0040-8166(97)80052-3, 1997.

Edgerton, M. D.: Increasing crop productivity to meet global needs for feed, food, and fuel, Plant Physiol., 149, 7-13, https://doi.org/10.1104/pp.108.130195, 2009.

EFSA: Risk profile related to production and consumption of insects as food and feed, EFSA J., 13, https://doi.org/10.2903/j.efsa.2015.4257, 2015.

Ellis, J. L., Bannink, A., France, J., Kebreab, E., and Dijkstra, J.: Evaluation of enteric methane prediction equations for dairy cows used in whole farm models, Glob. Change Biol., 16, 32463256, https://doi.org/10.1111/j.1365-2486.2010.02188.x, 2010.

Ertl, P., Klocker, H., Hortenhuber, S., Knaus, W., and Zollitsch, W.: The net contribution of dairy production to human food supply: The case of Austrian dairy farms, Agr. Syst., 137, 119-125, https://doi.org/10.1016/j.agsy.2015.04.004, 2015.

FAO: How to Feed the World in 2050, High-Level Expert Forum, Rome, Italy, p. 35, 2009.

FAO: Global Food Losses and Food Waste - Extent, causes and prevention, Rome, Italy, p. 37, 2011.

FAO: FAO Statistical Yearbool, FAO, Rome, Italy, 2013. 
FAO, IFAD, and WFP: The State of Food Insecurity in the World 2014 - Strengthening the Enabling Environment for Food Security and Nutrition, FAO, Rome, Italy, 2014.

FAO: Sustainable Land Management (SLM) in Practice in the Kagera Basin. Lessons Learned for Scaling up at Landscape Level - Results of the Kagera Transboundary Agro-ecosystem Management Project (Kagera TAMP), Rome, Italy, p. 440, 2017.

Finke, M. D.: Complete nutrient composition of commercially raised invertebrates used as food for insectivores, Zoo Biol., 21, 269-285, https://doi.org/10.1002/zoo.10031, 2002.

Flachowsky, G.: Stroh als Futterittel, Deutscher Landwirtschaftsverlag, Berllin, Germany, 255 pp., 1987.

Flachowsky, G.: Efficiency of energy and nutrient use in the production of edible protein of animal origin, J. Appl. Anim. Res., 22, 1-24, 2002.

Flachowsky, V. G. and Brade, W.: Reduction potentials for methane emissions from ruminants, Zuchtungskunde, 79, 417-465, 2007.

Flachowsky, G. and Hachenberg, S.: $\mathrm{CO}_{2}$-footprints for food of animal origin - present stage and open questions, J. Verbrauch. Lebensm., 4, 190-198, https://doi.org/10.1007/s00003009-0481-6, 2009.

Flachowsky, G. and Kamphues, J.: Carbon footprints for food of animal origin: what are the most preferable criteria to measure animal yields?, Animals, 2, 108-126, https://doi.org/10.3390/ani2020108, 2012.

Flachowsky, G. and Klüß, J.: Insects as feedstuffs?, Feed Magazine, 98, 9-13, 2015.

Flachowsky, G. and Meyer, U.: Sustainable production of protein of animal origin - the state of knowledge. Part 1. Resources and emissions as factors affecting sustainbility, J. Anim. Feed Sci., 24, 273-282, 2015a.

Flachowsky, G. and Meyer, U.: Challenges for plant breeders from the view of animal nutrition, Agriculture, 5, 1252-1276, https://doi.org/10.3390/agriculture5041252, 2015b.

Flachowsky, G. and Meyer, U.: Sustainable production of protein of animal origin - the state of knowledge. Part 2. Aquirements, objectives and ways of sustainbility improvement, J. Anim. Feed Sci., 24, 283-294, 2015c.

Flachowsky, G. and Meyer, U.: Global challenges for a sustainable production of food of animal origin, EC Nutrition, 9, 223-227, 2017.

Flachowsky, G., Dänicke, S., Lebzien, P., and Meyer, U.: Resource efficient produced food of animal origin, Ernährung, 37, 207210, 2013a.

Flachowsky, G., Grün, M., and Meyer, U.: Feed-efficient ruminant production: opportunities and challenges, J. Anim. Feed Sci., 22, 177-187, 2013b.

Flachowsky, G., Meyer, U., and Südekum, K.-H.: Land use for edible protein of animal origin - a review, Animals, 7, 1-19, https://doi.org/10.3390/ani7030025, 2017.

Forbes, J. M.: The Voluntary Food Intake of Farm Animals, Butterworth, London, UK, 216 pp., 1986.

Frorip, J., Kokin, E., Praks, J., Poikalainen, V., Ruus, A., Veermäe, I., Lepasalu, L., Schäfer, W., Mikkola, H., and Ahokas, J.: Energy consumption in animal production - case farm study, Agronomy Research, 10, 39-48, 2012.

Gerbens-Leenes, P. W., Mekonnen, M. M., and Hoekstra, A. Y.: The water footprint of poultry, pork and beef: A comparative study in different countries and production systems, Water Resour. Industry, 1-2, 25-36, https://doi.org/10.1016/j.wri.2013.03.001, 2013.

GfE: Empfehlungen zur Energie und Nährstoffversorgung der Mastrinder, Energie- und Nährstoffbedarf landwirtschaftlicher Nutztiere, DLG-Verlag, Frankfurt am Main, 85 pp., 1995.

GfE: Empfehlungen zur Energie und Nährstoffversorgung der der Legehennen und Masthühner (Broiler), Energie- und Nährstoffbedarf landwirtschaftlicher Nutztiere, DLG-Verlag, Frankfurt am Main, 185 pp., 1999.

GfE: Empfehlungen zur Energie und Nährstoffversorgung der Milchkühe und Aufzuchtrinder, Energie- und Nährstoffbedarf landwirtschaftlicher Nutztiere, DLG-Verlag, Frankfurt am Main, 136 pp., 2001.

GfE: Recommendations for the supply of energy and nutrients to pigs, Energie- und Nährstoffbedarf landwirtschaftlicher Nutztiere, DLG-Verlag, Frankfurt am Main, No. 10, 248 pp., , 2008.

GfE: Empfehlungen zur Energie- und Nährstoffversorgung von Pferden, Energie- und Nährstoffbedarf landwirtschaftlicher Nutztiere, DLG-Verlag, Frankfurt am Main, No. 11, 192 pp., 2014.

Gill, B. P.: Water Use by Pigs Managed Under Various Conditions of Housing, Feeding and Nutrition, PhD, Plymouth Polytechnic, Plymouth, UK, 308 pp., 1989.

Grabow, M., Meyer, U., Abel, H., and Flachowsky, G.: Investigations on the water intake of growing heifers, Proceedings of the Society of Nutrition Physiology, DLG-Verlag, Frankfurt am Main, 99, 2009.

Grabowski, N. T., Nowak, B., and Klein, G.: Proximate chemical composition of long-horned and short-horned grasshoppers (Acheta domesticus, Schistocerca gregaria and Phymateus saxosus) available commercially in Germany, Arch. Lebensmittelhyg., 59, 204-208, 2008.

Guccione, A., Biondi, N., Sampietro, G., Rodolfi, L., Bassi, N., and Tredici, M. R.: Chlorella for protein and biofuels: from strain selection to outdoor cultivation in a Green Wall Panel photobioreactor, Biotechnol. Biofuels, 7, 84, https://doi.org/10.1186/17546834-7-84, 2014.

Guillou, M. and Matheron, G.: The World's Challenge - Feeding 9 Billion People, Springer Netherlands, Berlin, Germany, 2014.

Guyomard, H., Darcy-Vrillon, B., Esnouf, C., Marin, M., Russel, M., and Guillou, M.: Eating patterns and food systems: critical knowledge requirements for policy design and implementation, Agric. Food Security, 1, 13, https://doi.org/10.1186/20487010-1-13, 2012.

Hall, D. C. and Hall, J. V.: Concepts and measures of naturalresource scarcity with a summary of recent trends, J. Environ. Econ. Manag., 11, 363-379, https://doi.org/10.1016/00950696(84)90005-6, 1984.

Hergoualch, K. and Verchot, L. V.: Stocks and fluxes of carbon associated with land use change in Southeast Asian tropical peatlands: a review, Global Biogeochem. Cy., 25, GB2001, https://doi.org/10.1029/2009gb003718, 2011.

Hoekstra, A. Y.: The water footprint of animal products, in: The Meat Crisis: Developing More Sustainable Production and Consumption, edited by: D'Silva, J. and Webster, J., Earthscan, London, UK, 22-33, 2010. 
Hoekstra, A. Y.: A critique on the water-scarcity weighted water footprint in LCA, Ecol. Indic., 66, 564-573, https://doi.org/10.1016/j.ecolind.2016.02.026, 2016.

Holter, J. B. and Urban, W. E.: Water partitioning and intake prediction in dry and lactating Holstein Cows, J. Dairy Sci., 75, 14721479, 1992.

Hörtenhuber, S., Piringer, G., Zollitsch, W., Lindenthal, T., and Winiwarter, W.: Land use and land use change in agricultural life cycle assessments and carbon footprints - the case for regionally specific land use change versus other methods, J. Clean. Prod., 73, 31-39, https://doi.org/10.1016/j.jclepro.2013.12.027, 2014.

IPCC: Guidelines for National Greenhouse Gas Inventories - Agriculture, Forestrry and other Land Use, edited by: Eggleston, S., Buendia, L., Miwa, K., Ngara, T., and Tanabe, K., Hayama, Kanagawa, Japan, 2006.

IPCC: Climate Change 2014, Mitigation of Climate Change Working Group III Contribution to the fifth Assessment Report of the Intergovernmental Panel on Climate Change, edited by: Edendorfer, O., Pichs-Madruga, R., and Sokona, Y., Cambridge University Press, New York, NY, USA, 2014.

Jentsch, W., Schiemann, R., Wittenburg, H., and Hoffmann, L.: Investigations into digestibility and utilization of rations containing differently treated straw. 2 . Studies into energetic utilization by sheep of rations containing differently treated straw, Arch. Tierernähr., 28, 397-406, 1978a.

Jentsch, W., Wittenburg, H., and Schiemann, R.: Investigations into digestibility and utilization of rations containing differently treated straw. 3. Studies regarding energetic utilization by fattening bulls of rations containing differently treated straw, Arch. Tierernähr., 28, 407-416, 1978b.

Jeroch, H., Flachowsky, G., and Weissbach, F.: Futtermittelkunde, Gustav Fischer Verlag, Jena, Germany, 510 pp., 1993.

Jokiniemi, T., Mikkola, H., Rossner, H., Talgre, L., Lauringson, E., Hovi, M., and Ahokas, J.: Energy savings in plant production, Agronomy Research, 10, 85-96, 2012.

Jordaan, H. and Bergman, M. M.: Towards a Sustainable Agriculture: Farming Practices and Water Use Frontiers in Sustainability Series 1, MDPI Books Basel, Switzerland, 120 pp., 2017.

Kamphues, J., Bohm, R., Flachowsky, G., Lahrssen-Wiederholt, M., Meyer, U., and Schenkel, H.: Recommendations for evaluating the hygienic quality of drinking water for food producing animals in accordance with current regulatory framework (Empfehlungen zur Beurteilung der hygienischen Qualität von Tränkwasser für Lebensmittel liefernde Tiere unter Berücksichtigung der gegebenen rechtlichen Rahmenbedingungen), Landbauforsch. Volk., 57, 255-272, 2007.

Kamphues, J., Coenen, M., Eder, K., Iben, C., Kienzle, E., Liesegang, A., Zebeli, Q., and Zentek, J.: Supplemente zur Tierernährung, M. \& H. Schaper, Hannover, Germany, 2014.

Kastner, T., Rivas, M. J. I., Koch, W., and Nonhebel, S.: Global changes in diets and the consequences for land requirements for food, P. Natl. Acad. Sci. USA, 109, 6868-6872, https://doi.org/10.1073/pnas.1117054109, 2012.

Kim, H., Kim, S., and Dale, B. E.: Biofuels, land use change, and greenhouse gas emissions: some unexplored variables, Environ. Sci. Technol., 43, 961-967, https://doi.org/10.1021/es802681k, 2009.

Knaus, W.: Re-thinking dairy cow feeding in light of food security, AgroLife Sci. J., 2, 36-40, 2012.
Kolb, E.: Lehrbuch der Physiologie der Haustiere, Gustav-FischerVerlag, Jena, Germany, 1989.

Kool, A., Marinussen, M., and Blonk, H.: LCI Data for the Calculation Tool Feedprint for Greenhouse Gas Emissions of Feed Production and Utilization - GHG Emissions of N, P and K Fertilizer Production, Blonk Consultants, Gouda, the Netherlands, 15 pp., 2012.

Krauss, M., Drastig, K., Prochnow, A., Rose-Meierhofer, S., and Kraatz, S.: Drinking and Cleaning Water Use in a Dairy Cow Barn, Water-Sui, 8, 302, https://doi.org/10.3390/W8070302, 2016.

Lampe, C., Dittert, K., Sattelmacher, B., Wachendorf, M., Loges, R., and Taube, F.: Sources and rates of nitrous oxide application of ${ }^{15} \mathrm{~N}$-labelled emissions from grazed grassland after mineral fertilizer and slurry, Soil Biol. Biochem., 38, 2602-2613, https://doi.org/10.1016/j.soilbio.2006.03.016, 2006.

Legesse, G., Ominski, K. H., Beauchemin, K. A., Pfister, S., Martel, M., McGeough, E. J., Hoekstra, A. Y., Kroebel, R., Cordeiro, M. R. C., and McAllister, T. A.: BOARD-INVITED REVIEW: Quantifying water use in ruminant production, J. Anim. Sci., 95, 2001-2018, https://doi.org/10.2527/jas2017.1439, 2017.

Lesschen, J. P., van den Berg, M., Westhoek, H. J., Witzke, H. P., and Oenema, O.: Greenhouse gas emission profiles of European livestock sectors, Anim. Feed Sci. Tech., 166-167, 16-28, https://doi.org/10.1016/j.anifeedsci.2011.04.058, 2011.

Lundy, M. E. and Parrella, M. P.: Crickets are not a free lunch: protein capture from scalable organic side-streams via high-density populations of Acheta domesticus, PLoS ONE, 10, e0118785, https://doi.org/10.1371/journal.pone.0118785, 2015.

Makkar, H. P. S.: Biofuel Co-Products as Livestock Feed - Opportunities and Challenges, Food and Agriculture Organization of the United Nations (FAO), Rome, XVIII + 533 pp., 2012.

Makkar, H. P. S. and Ankers, P.: Towards sustainable animal diets: a survey-based study, Anim. Feed Sci. Tech., 198, 309-322, https://doi.org/10.1016/j.anifeedsci.2014.09.018, 2014.

Makkar, H. P. S., Tran, G., Henze, V., and Ankers, P.: State-of-theart on use of insects as animal feed, Anim. Feed Sci. Tech., 197, 1-33, https://doi.org/10.1016/j.anifeedsci.2014.07.008, 2014.

Martin-Rosset, W., Tavernier, L., Trillaud-Geyl, C., and Cabaret, J.: Diet formulation, in: Equine Nutrition, edited by: MartinRosset, W., Wageningen Academic Publisher, Wageningen, the Netherlands, 97-120, 2015.

Mekonnen, M. M. and Hoekstra, A. Y.: A global assessment of the water footprint of farm animal products, Ecosystems, 15, 401415, https://doi.org/10.1007/s10021-011-9517-8, 2012.

Mendieta-Araica, B., Sporndly, R., Reyes-Sanchez, N., and Sporndly, E.: Moringa (Moringa oleifera) leaf meal as a source of protein in locally produced concentrates for dairy cows fed low protein diets in tropical areas, Livest. Sci., 137, 10-17, https://doi.org/10.1016/j.livsci.2010.09.021, 2011.

Meyer, U., Everinghoff, M., Gädeken, D., and Flachowsky, G.: Investigations on the water intake of lactating dairy cows, Livest. Prod. Sci., 90, 117-121, https://doi.org/10.1016/j.livprodsci.2004.03.005, 2004.

Meyer, U., Stahl, W., and Flachowsky, G.: Investigations on the water intake of growing bulls, Livest. Sci., 103, 186-191, https://doi.org/10.1016/j.livsci.2006.02.009, 2006. 
Mikkola, H. J. and Ahokas, J.: Energy ratios in Finnish agricultural production, Agr. Food Sci., 18, 332-346, 2009.

Montes, F., Meinen, R., Dell, C., Rotz, A., Hristov, A. N., Oh, J., Waghorn, G., Gerber, P. J., Henderson, B., Makkar, H. P. S., and Dijkstra, J.: SPECIAL TOPICS - Mitigation of methane and nitrous oxide emissions from animal operations: II. A review of manure management mitigation options, J. Anim. Sci., 91, 50705094, https://doi.org/10.2527/jas.2013-6584, 2013.

Mungkung, R., Aubin, J., Prihadi, T. H., Slernbrouck, J., van der Werf, H. M. G., and Legendre, M.: Life Cycle Assessment for environmentally sustainable aquaculture management: a case study of combined aquaculture systems for carp and tilapia, J. Clean. Prod., 57, 249-256, https://doi.org/10.1016/j.jclepro.2013.05.029, 2013.

Murphy, M. R., Davis, C. L., and Mccoy, G. C.: Factors affecting water-consumption by Holstein Cows in early lactation, J. Dairy Sci., 66, 35-38, 1983.

Nagai, M., Hachimura, K., and Takahashi, K.: Water-consumption in suckling pigs, J. Vet. Med. Sci., 56, 181-183, 1994.

National Academies of Sciences: Engineering, and Medicine: Genetically Engineered Crops: Experiences and Prospects, The National Academies Press, Washington, DC, 606 pp., 2016.

Neumann, C., Harris, D. M., and Rogers, L. M.: Contribution of animal source foods in improving diet quality and function in children in the developing world, Nutr. Res., 22, 193-220, https://doi.org/10.1016/S0271-5317(01)00374-8, 2002.

Niemann, H., Kuhla, B., and Flachowsky, G.: Perspectives for feed-efficient animal production, J. Anim. Sci., 89, 4344-4363, https://doi.org/10.2527/jas.2011-4235, 2011.

Nijdam, D., Rood, T., and Westhoek, H.: The price of protein: Review of land use and carbon footprints from life cycle assessments of animal food products and their substitutes, Food Policy, 37, 760-770, https://doi.org/10.1016/j.foodpol.2012.08.002, 2012.

NRC: Nutrient Requirements of Swine: 10th Revised Edn., The National Academies Press, Washington, DC, 212 pp., 1998.

NRC: Nutrient Requirements of Dairy Cattle: 7th Revised Edn., The National Academies Press, Washington, DC, 2001.

NRC: Nutrient Requirements of Small Ruminants: Sheep, Goats, Cervids, and New World Camelids, The National Academies Press, Washington, DC, 384 pp., 2007.

NRC: Toward Sustainable Agr. Syst. in the 21st Century, The National Academies Press, Washington, DC, 598 pp., 2010.

NRC: Critical Role of Animal Science Research in Food Security and Sustainability, The National Academies Press, Washington, DC, USA, 415 pp., 2015.

Ochrimenko, W. I., Flachowsky, G., Lohnert, H. J., and Hennig, A.: Studies of the use of differently treated wheat straw in the feeding of fattening cattle under special consideration of wet straw preserved with urea. 1. Method of the experiment and fattening results with an equal intake of organic-matter from the straw (pair fed), Arch. Tierernähr., 36, 895-904, 1986.

OECD/FAO: OECD-FAO Agricultural Outlook 2017-2026, OECD Publishing, Paris, France, 142 pp., 2017.

Oonincx, D. G. A. B., van Itterbeeck, J., Heetkamp, M. J. W., van den Brand, H., van Loon, J. J. A., and van Huis, A.: An exploration on greenhouse gas and ammonia production by insect species suitable for animal or human consumption, PLoS ONE, 5, e14445, https://doi.org/10.1371/journal.pone.0014445, 2010.
Oonincx, D. G. A. B. and de Boer, I. J. M.: Environmental impact of the production of mealworms as a protein source for humans - a life cycle assessment, PLoS ONE, 7, e51145, https://doi.org/10.1371/journal.pone.0051145, 2012.

Pape, H. C.: Futtermittelzusatzstoffe: Technologie und Anwendung, Agrimedia, Bergen/Dumme, Germany, 2006.

Parfitt, J., Barthel, M., and Macnaughton, S.: Food waste within food supply chains: quantification and potential for change to 2050, Philos. T. Roy. Soc. B, 365, 3065-3081, https://doi.org/10.1098/rstb.2010.0126, 2010.

Parisi, C., Tillie, P., and Rodriguez-Cerezo, E.: The global pipeline of GM crops out to 2020, Nat. Biotechnol., 34, 31-36, https://doi.org/10.1038/nbt.3449, 2016.

Peters, C. J., Wilkins, J. L., and Fick, G. W.: Testing a completediet model for estimating the land resource requirements of food consumption and agricultural carrying capacity: the New York State example, Renew. Agr. Food Syst., 22, 145-153, https://doi.org/10.1017/S1742170507001767, 2007.

Peters, G. M., Rowley, H. V., Wiedemann, S., Tucker, R., Short, M. D., and Schulz, M.: Red Meat Production in Australia: Life Cycle Assessment and Comparison with Overseas Studies, Environ. Sci. Technol., 44, 1327-1332, https://doi.org/10.1021/es901131e, 2010.

Pimentel, D. and Pimentel, M.: Sustainability of meat-based and plant-based diets and the environment, Am. J. Clin. Nutr., 78, 660s-663s, 2003.

Pimentel, D., Berger, B., Filiberto, D., Newton, M., Wolfe, B., Karabinakis, E., Clark, S., Poon, E., Abbett, E., and Nandagopal, S.: Water resources: Agricultural and environmental issues, Bioscience, 54, 909-918, https://doi.org/10.1641/00063568(2004)054[0909:Wraaei]2.0.Co;2, 2004.

Post, M. J.: Cultured beef: medical technology to produce food, J. Sci. Food Agr., 94, 1039-1041, https://doi.org/10.1002/jsfa.6474, 2014a.

Post, M. J.: An alternative animal protein source: cultured beef, Ann. NY Acad. Sci., 1328, 29-33, https://doi.org/10.1111/nyas.12569, 2014b.

Rathke, G.-W., Körschens, M., and Diepenbrock, W.: Substance and energy balances in the "Static Fertilisation Experiment Bad Lauchstädt”, Arch. Agron. Soil Sci., 48, 423-433, https://doi.org/10.1080/03650340215652, 2002.

Rathke, G. W. and Diepenbrock, W.: Energy balance of winter oilseed rape (Brassica napus L.) cropping as related to nitrogen supply and preceding crop, Eur. J. Agron., 24, 35-44, https://doi.org/10.1016/j.eja.2005.04.003, 2006.

Ridoutt, B. G., Page, G., Opie, K., Huang, J., and Bellotti, W.: Carbon, water and land use footprints of beef cattle production systems in southern Australia, J. Clean. Prod., 73, 24-30, https://doi.org/10.1016/j.jclepro.2013.08.012, 2014.

Rumpold, B. A. and Schluter, O. K.: Nutritional composition and safety aspects of edible insects, Mol. Nutr. Food Res., 57, 802 823, https://doi.org/10.1002/mnfr.201200735, 2013.

Sanchez-Muros, M. J., Barroso, F. G., and ManzanoAgugliaro, F.: Insect meal as renewable source of food for animal feeding: a review, J. Clean. Prod., 65, 16-27, https://doi.org/10.1016/j.jclepro.2013.11.068, 2014.

Schiavon, S. and Emmans, G. C.: A model to predict water intake of a pig growing in a known environment on a known diet, Brit. J. Nutr., 84, 873-883, 2000. 
Schlink, A. C., Nguyen, M. L., and Viljoen, G. J.: Water requirements for livestock production: a global perspective, Rev. Sci. Tech. OIE, 29, 603-619, 2010.

Schmeer, M., Loges, R., Dittert, K., Senbayram, M., Horn, R., and Taube, F.: Legume-based forage production systems reduce nitrous oxide emissions, Soil Till. Res., 143, 17-25, https://doi.org/10.1016/j.still.2014.05.001, 2014.

Scholz, R. W. and Wellmer, F.-W.: Approaching a dynamic view on the availability of mineral resources: What we may learn from the case of phosphorus?, Global Environ. Chang., 23, 11-27, https://doi.org/10.1016/j.gloenvcha.2012.10.013, 2013.

Smith, J., Sones, K., Grace, D., MacMillan, S., Tarawali, S., and Herrero, M.: Beyond milk, meat, and eggs: role of livestock in food and nutrition security, Animal Frontiers, 3, 6-13, https://doi.org/10.2527/af.2013-0002, 2013.

Souci, S. W., Fachmann, W., and Kraut, H.: Food Composition and Nutrition Tables, 7th revised Edn., MedPharm Scientific Publishers and Taylor \& Francis, A CRC Press Book, Boca Raton, USA, 1300 pp., 2006.

St-Hilaire, S., Cranfill, K., McGuire, M. A., Mosley, E. E., Tomberlin, J. K., Newton, L., Sealey, W., Sheppard, C., and Irving, S.: Fish offal recycling by the black soldier fly produces a foodstuff high in omega-3 fatty acids, J. World Aquacult. Soc., 38, 309313, https://doi.org/10.1111/j.1749-7345.2007.00101.x, 2007.

Stevens, R. J., Laughlin, R. J., Burns, L. C., Arah, J. R. M., and Hood, R. C.: Measuring the contributions of nitrification and denitrification to the flux of nitrous oxide from soil, Soil Biol. Biochem., 29, 139-151, https://doi.org/10.1016/S00380717(96)00303-3, 1997.

Talgre, L., Lauringson, E., Roostalu, H., Astover, A., Eremeev, V., and Selge, A.: The effects of pure and undersowing green manures on yields of succeeding spring cereals, Acta Agr. Scand. BS. P., 59, 70-76, https://doi.org/10.1080/09064700801906198, 2009.

Tedeschi, L. O. and Fox, D. D.: The Ruminant Nutrition System: an Applied Model for Predicting Nutrient Requirements and Feed Utilization in Ruminants, XanEdu, Ann Arbor, MI, USA, 545 pp., 2016.

Thorup-Kristensen, K., Magid, J., and Jensen, L. S.: Catch crops and green manures as biological tools in nitrogen management in temperate zones, Adv. Agron., 79, 227-302, https://doi.org/10.1016/S0065-2113(02)79005-6, 2003.

Thulin, A. J. and Brumm, M. C.: Water - the forgotten nutrient, in: Swine Nutrition, edited by: Miller, E. R., Ullrey, D. E., and Lewis, A. J., Butterworth-Heinemann, Boston, USA, 315-339, 1991.

Thyberg, K. L. and Tonjes, D. J.: The environmental impacts of alternative food waste treatment technologies in the US, J. Clean. Prod., 158, 101-108, https://doi.org/10.1016/j.jclepro.2017.04.169, 2017.

Tilman, D., Balzer, C., Hill, J., and Befort, B. L.: Global food demand and the sustainable intensification of agriculture, P. Natl. Acad. Sci. USA, 108, 20260-20264, https://doi.org/10.1073/pnas.1116437108, 2011.
Tompson, B. and Amoroso, L.: Improving Diets and Nutrition Food-Based Approaches, CAB International, Wallingford, UK, 403 pp., 2014.

Tredici, M. R.: Photobiology of microalgae mass cultures: understanding the tools for the next green revolution, Biofuels, 1, 143162, https://doi.org/10.4155/bfs.09.10, 2010.

USDA Food Composition Databases, National Nutrient Database for Standard Reference (released 28 September 2015, slightly revised May 2016), available at: https://ndb.nal.usda.gov/ndb/ (last access: 2 August 2017), 2016.

van Groenigen, J. W., Velthof, G. L., van der Bolt, F. J. E., Vos, A., and Kuikman, P. J.: Seasonal variation in $\mathrm{N}_{2} \mathrm{O}$ emissions from urine patches: Effects of urine concentration, soil compaction and dung, Plant Soil, 273, 15-27, https://doi.org/10.1007/s11104-004-6261-2, 2005.

van Huis, A.: Potential of insects as food and feed in assuring food security, Annu. Rev. Entomol., 58, 563-583, https://doi.org/10.1146/annurev-ento-120811-153704, 2013.

Vandehaar, M. J.: Symposium: Efficiency of production - efficiency of nutrient use and relationship to profitability on dairy farms, J. Dairy Sci., 81, 272-282, 1998.

Weisskopf, P., Reiser, R., Rek, J., and Oberholzer, H. R.: Effect of different compaction impacts and varying subsequent management practices on soil structure, air regime and microbiological parameters, Soil Till. Res., 111, 65-74, https://doi.org/10.1016/j.sti11.2010.08.007, 2010.

Wellmer, F.-W., and Scholz, R. W.: Peak minerals: What can we learn from the history of mineral economics and the cases of gold and phosphorus?, Mineral Economics, 30, 73-93, https://doi.org/10.1007/s13563-016-0094-3, 2016.

Wellmer, F.-W., and Scholz, R.: Putting phosphorus first: the need to know and right to know call for a revised hierarchy of natural resources, Resources, 6, 20-27, https://doi.org/10.3390/resources6020020, 2017.

WHO: Guidelines for Drinking-Water Quality - First Addendum to Third Edn. - Volume 1 - Recommendations, Guidelines for Drinking-Water Quality, Geneva, Switzerland, 31 pp., 2006.

Wilkinson, J. M.: Re-defining efficiency of feed use by livestock, Animal, 5, 1014-1022, https://doi.org/10.1017/S175173111100005x, 2011.

Windisch, W., Fahn, C., Brugger, D., Deml, M., and Buffler, M.: Strategies for sustainable animal nutrition, Zuchtungskunde, 85, 40-53, 2013.

Zepka, L. Q., Jacob-Lopes, E., Goldbeck, R., SouzaSoares, L. A., and Queiroz, M. I.: Nutritional evaluation of single-cell protein produced by Aphanothece microscopica Nageli, Bioresource Technol., 101, 7107-7111, https://doi.org/10.1016/j.biortech.2010.04.001, 2010.

Zonderland-Thomassen, M. A., Lieffering, M., and Ledgard, S. F.: Water footprint of beef cattle and sheep produced in New Zealand: water scarcity and eutrophication impacts, J. Clean. Prod., 73, 253-262, https://doi.org/10.1016/j.jclepro.2013.12.025, 2014. 